(2) Open Access Full Text Article

REVIEW

\title{
Development of treatment options for Chinese patients with advanced squamous cell lung cancer: focus on afatinib
}

This article was published in the following Dove Medical Press journal:

OncoTargets and Therapy

\author{
Shun Lu \\ Shanghai Lung Cancer Center, \\ Shanghai Chest Hospital, Shanghai \\ Jiao Tong University, Shanghai 200030, \\ China
}

Correspondence: Shun Lu Shanghai Lung Cancer Center, Shanghai Chest Hospital, Shanghai Jiao Tong University, 24I West Huaihai Road, Xuhui District, Shanghai 200030, China Tel +86 2I 22200000

Fax +86 2l 64085875

Email shun_lu@hotmail.com

\begin{abstract}
Lung cancer is the leading cause of cancer death in China, and approximately one third of these cancers are squamous cell carcinoma (SqCC) of the lung. Ethnic diversity and country-specific environmental factors can account for interindividual variations in response to and tolerability of anticancer therapies. Although several targeted therapies have recently been approved for patients with relapsed/refractory SqCC of the lung, only afatinib, an irreversible ErbB family blocker, has data of Chinese patients. In the Phase III LUX-Lung 8 trial, afatinib demonstrated a significant clinical benefit vs the reversible first-generation EGFR tyrosine kinase inhibitor erlotinib in both the overall population and the Chinese subset, with a manageable safety profile. Emerging biomarker data from LUX-Lung 8 suggest that patients with ErbB mutations, especially ErbB2, and those classified as "good" in the VeriStrat ${ }^{\mathbb{R}}$ proteomic test, may benefit from afatinib treatment in particular, regardless of ethnicity, and may get a long-term response. In conclusion, afatinib is a valid second-line option for Chinese patients with SqCC of the lung, and specific biomarkers may help guide in treatment decision-making. Ongoing studies will provide further guidance on afatinib's place in the treatment algorithm, alongside the other novel targeted therapies.
\end{abstract}

Keywords: squamous cell carcinoma, NSCLC, Chinese, afatinib, EGFR, ErbB, biomarker

\section{Introduction}

In China, lung cancer is the leading cause of cancer death ${ }^{1}$ and the rates of lung cancer diagnoses are rising. ${ }^{2}$ Although smoking rates in China have declined in recent years, ${ }^{3}$ cigarette smoking is still common, with $52.9 \%$ of Chinese men and $2.4 \%$ of women being smokers in 2010, representing about one third of the world's smoking population. ${ }^{4,5}$ The trend in smoking prevalence in China over the past 20-30 years has followed patterns in the USA observed in the 1970s and 1980s, ${ }^{6}$ and the burden of lung cancer is therefore increasing in China, as it did previously in the US population (Figure 1). ${ }^{5-7}$

Squamous cell carcinoma (SqCC) of the lung is strongly associated with smoking, ${ }^{8}$ and about $30 \%$ of lung cancers in China are SqCC histology. ${ }^{7}$ Although this is similar to the percentage of cases of SqCC of the lung in the US, ${ }^{8}$ the actual patient numbers are much higher due to the size of the Chinese population. Therefore, there is an urgent need to identify optimal treatments for SqCC of the lung in the Chinese population.

While molecularly targeted therapy has revolutionized the treatment of patients with EGFR mutation-positive and anaplastic lymphoma kinase-positive non-small-cell 


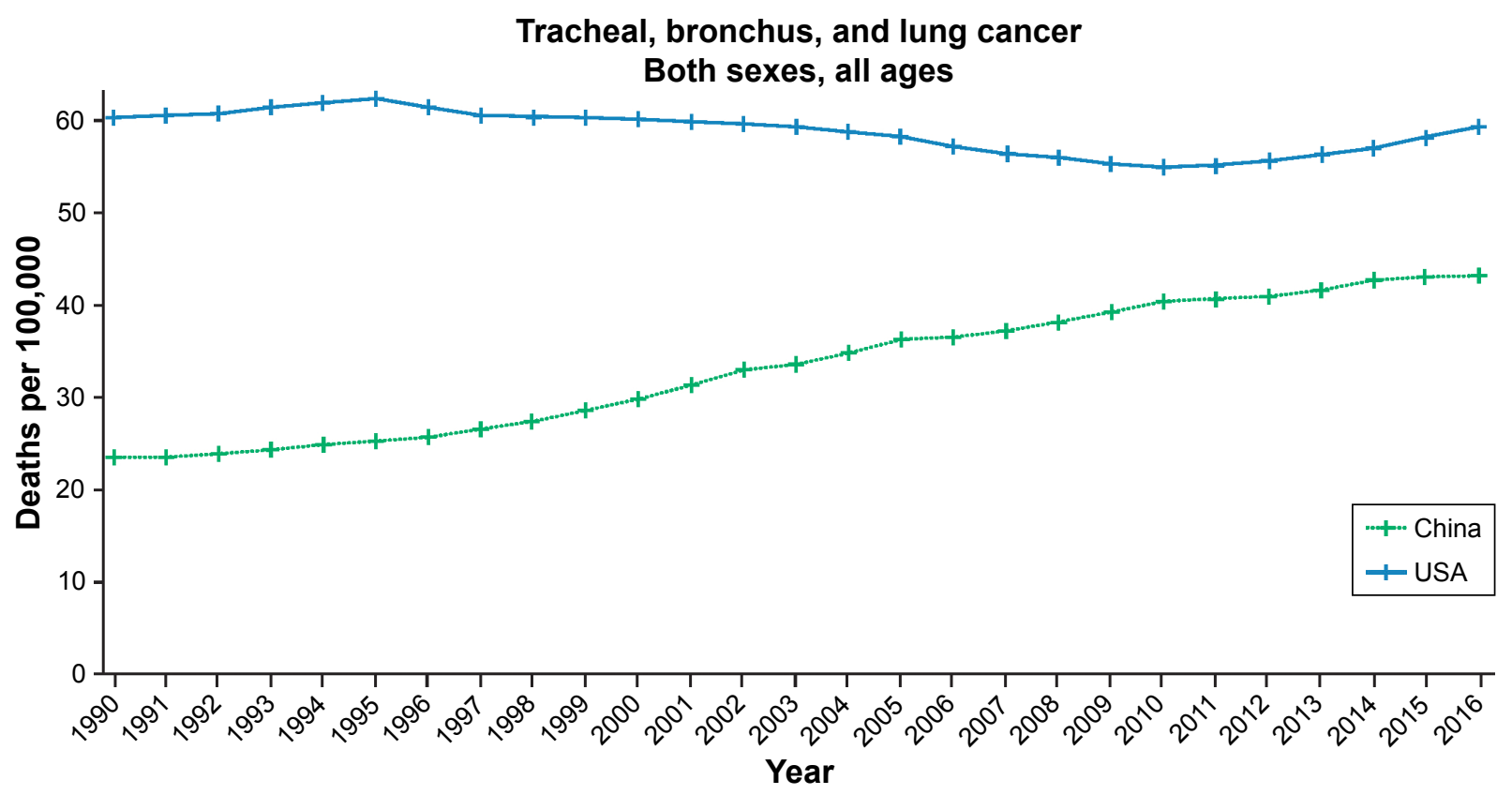

Figure I Deaths caused by lung cancer in China and the USA from I990 to 2016.

Notes: Institute for Health Metrics and Evaluation (IHME). GBD Compare. Seattle, WA: IHME, University of Washington; 20I7. Available from: http://vizhub.healthdata.org/ gbd-compare. Accessed January 15, 2019.87

lung cancer (NSCLC), progress in the treatment of SqCC of the lung, which is typically EGFR wild-type, has been slower. Although platinum-doublet chemotherapy remains the standard first-line treatment for patients with advanced stage of $\mathrm{SqCC}$ of the lung in China, as elsewhere, ${ }^{9,10}$ outcomes are generally modest. In addition, second-line treatment options are limited. Until recently, erlotinib (an EGFR tyrosine kinase inhibitor [TKI]) and docetaxel were the only agents approved in this setting, ${ }^{9,11}$ highlighting the unmet need in this patient population.

Since 2014, several targeted therapies have been approved for the treatment of SqCC of the lung. ${ }^{9}$ These include the following: necitumumab, an anti-EGFR monoclonal antibody, which is approved for the first-line use, in combination with standard chemotherapy; ${ }^{12,13}$ the immunotherapies pembrolizumab, nivolumab, and atezolizumab; the vascular endothelial growth factor receptor-2 (VEGFR-2) antibody, ramucirumab (in combination with docetaxel); and the second-generation EGFR-targeted TKI, afatinib (an irreversible ErbB family blocker that inhibits signaling from all ErbB heterodimers and homodimers), all of which have been approved as the second-line therapy., ${ }^{9,12-17}$ This recent expansion of therapeutics approved for the second-line use necessitates a discussion about optimal treatment choice.

Pharmacoethnicity, or ethnic diversity in drug response or toxicity, is recognized as an important factor accounting for an interindividual variation in anticancer therapy responsiveness. ${ }^{18}$ In addition to the environmental factors that influence bioavailability and metabolism, such as the frequency of smoking, the expression levels of the drug target and the prevalence of mutations in the target population must also be taken into account. ${ }^{19}$ Therefore, potential biomarkers to help guide clinicians as to the optimal treatment choice for their patients with SqCC of the lung, including those of Asian ethnicity, also need to be considered.

This article reviews targeted agents, including the recently approved afatinib for the treatment of $\mathrm{SqCC}$ of the lung, the only targeted therapy with data of Chinese patients available from its registration trial. This article also considers the use of biomarkers to identify suitable patient populations, and of afatinib in the treatment algorithm alongside the other novel agents, including immunotherapies.

\section{Targeting EGFR and other ErbB family proteins in SqCC of the lung}

Both first-line afatinib ${ }^{20,21}$ and the first-generation, reversible EGFR TKIs, gefitinib ${ }^{22-24}$ and erlotinib ${ }^{25-27}$ (Figure 2C), have been demonstrated to be superior to chemotherapy in patients with NSCLC and EGFR-activating mutations; more recent trials showed the second-/third-generation EGFR TKIs, afatinib, dacomitinib, and osimertinib, to be superior to the first-generation TKIs. ${ }^{28-31}$ Because EGFR mutations are relatively common in Asian patients, most of the trials were conducted in Asian populations. . $^{21,32,33}$

Although EGFR mutations are relatively uncommon in SqCC $($ Western population $=3.3 \%$; Asian population $=4.6 \%$; 


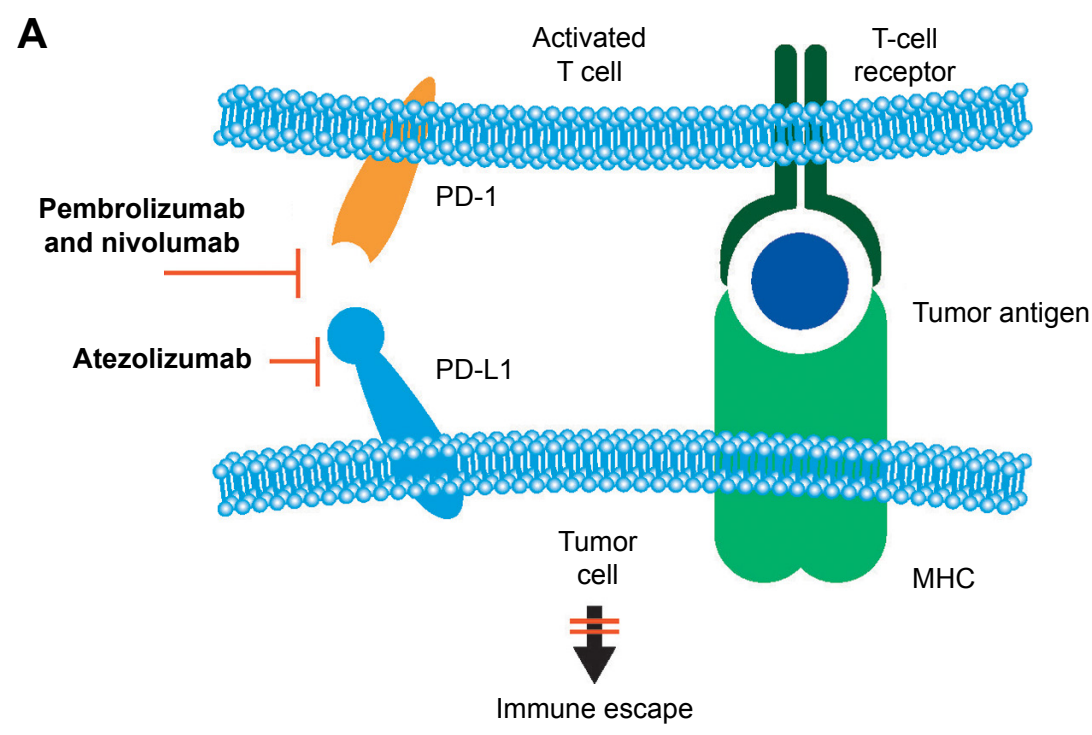

B

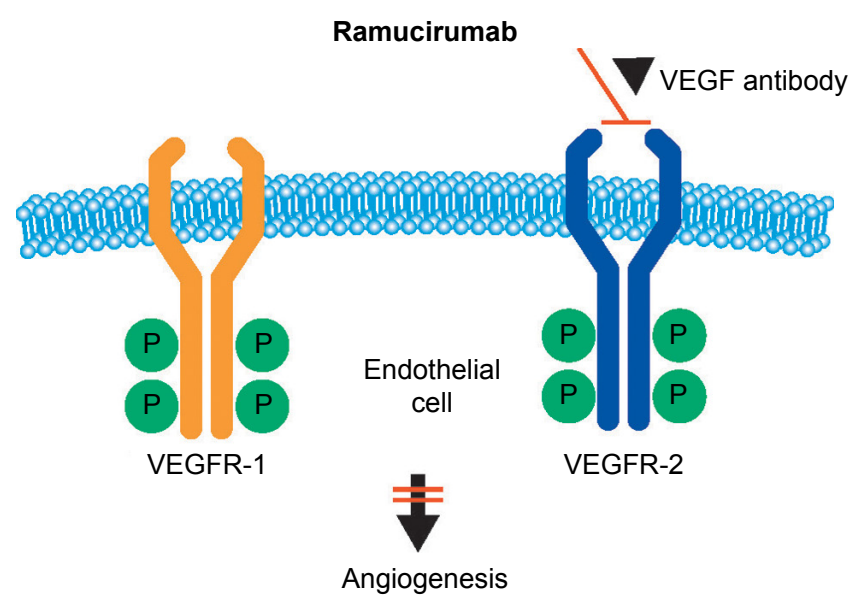

C

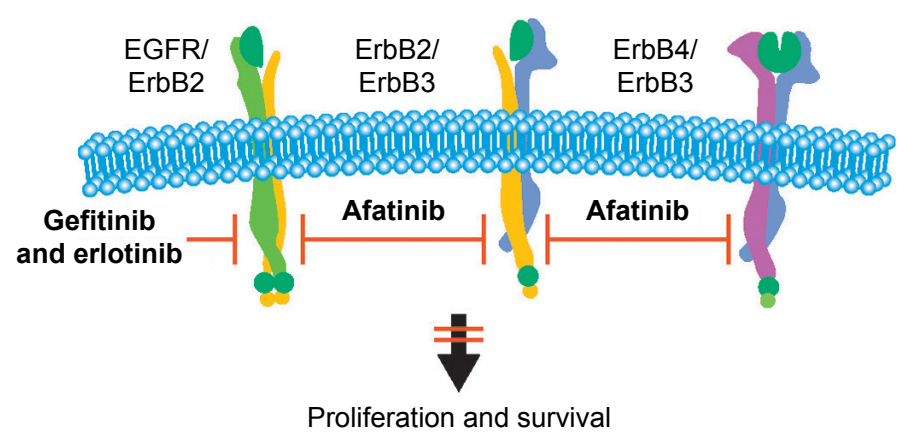

Figure 2 Mechanism of action of (A) immune checkpoint inhibitors, (B) VEGFR inhibitors, and (C) EGFR/ErbB inhibitors.

Abbreviations: MHC, major histocompatibility complex; PD-I, programmed cell death protein-I; PD-LI, programmed cell death ligand-I; VEGF, vascular endothelial growth factor; VEGFR, vascular endothelial growth factor receptor.

Table 1), ${ }^{34}$ EGFR overexpression is frequently observed $(50 \%-80 \%)^{35-39}$ and $7 \%-10 \%$ of tumors also have alterations in EGFR gene copy number. ${ }^{35,39,40}$ There is therefore a clear rationale for evaluating EGFR-targeted agents in SqCC of the lung, either combined with the first-line chemotherapy ${ }^{20,21}$ or as a monotherapy in patients with relapsed/refractory SqCC of the lung. ${ }^{41}$
In the Phase III SQUIRE trial in patients with previously untreated SqCC of the lung, the addition of necitumumab to gemcitabine plus cisplatin significantly improved overall survival (OS) vs gemcitabine plus cisplatin alone (median $=11.5$ vs 9.9 months, respectively $[\mathrm{HR}=0.84$, 95\% CI $=0.74-0.96 ; P=0.01]) .{ }^{13}$ However, a higher rate of grade $\geq 3$ adverse events (AEs) and serious AEs occurred 
Table I Incidence of individual mutations in Western and Asian $\mathrm{SqCC}^{34}$

\begin{tabular}{l|l|l}
\hline \multirow{2}{*}{ Gene } & \multicolumn{2}{|l}{ Incidence of mutation, $\mathbf{n} / \mathbf{N}(\%)$} \\
\cline { 2 - 3 } & Western & Asian \\
\hline TP53* & $62 / I 13(54.9)$ & $64 / 179(35.8)$ \\
EGFR* & $11 / 334(3.3)$ & $22 / 474(4.6)$ \\
KRAS* & $12 / 187(6.4)$ & $5 / 284(1.8)$ \\
LKBI* & $13 / 137(9.5)$ & $0 / 166(0.00)$ \\
EML4-ALK & $4 / 89(4.5)$ & $5 / 277(1.8)$ \\
PTEN* & $0 / 12(0.0)$ & $12 / 123(9.8)$ \\
BRAF* & $1 / 408(0.2)$ & $0 / 124(0.0)$ \\
PIK3CA & $1 / 71(1.4)$ & $8 / 124(6.5)$ \\
ErbB2 & $2 / 117(1.7)$ & $1 / 259(0.4)$ \\
\hline
\end{tabular}

Notes: *Significantly different, $P<0.001$. Copyright $\odot$ 2013, Oxford University Press. Dearden S, Stevens J, Wu YL, Blowers D. Mutation incidence and coincidence in non small-cell lung cancer: meta-analyses by ethnicity and histology (mutMap). Ann Oncol. 2013;24(9):237|-2376.34

Abbreviation: $\mathrm{SqCC}$, squamous cell carcinoma.

in patients treated with necitumumab plus gemcitabine and cisplatin. Of note, $8 \%$ of the patients were East Asian, but no efficacy data were reported for this subgroup. ${ }^{13}$ A meta-analysis of 2018 unselected patients with an advanced NSCLC also suggested that the addition of the anti-EGFR antibody cetuximab to standard platinum-doublets can provide a clinical benefit in patients with $\mathrm{SqCC}$ of the lung. ${ }^{42}$ While $7 \%$ of the patients were Asian, again no efficacy data were reported for this subgroup.

In the second-line setting, the subanalysis of the Phase III studies BR.21 (erlotinib vs placebo in relapsed/refractory NSCLC) $)^{43,44}$ and TAILOR (erlotinib vs docetaxel in patients with EGFR wild-type advanced NSCLC) $)^{45}$ indicated that erlotinib also has an activity against $\mathrm{SqCC}$ of the lung (Table 2). No data are available from either trial on the efficacy of erlotinib in Asian patients.

In addition to EGFR, other members of the ErbB family, particularly ErbB2 and ErbB3 and their downstream signaling pathways, also have a key role in the pathogenesis of SqCC of the lung. ${ }^{12,46-48}$ Approximately $18 \%$ of SqCC tumors express ErbB2 ${ }^{49}$ and around $30 \%$ of SqCC tumors overexpress ErbB3 ${ }^{48}$ Therefore, targeting just one branch of these degenerated ErbB pathways may offer a suboptimal treatment for squamous tumors. ${ }^{12}$ It was postulated that broader irreversible ErbB blockade with afatinib might

Table 2 Clinical activity of approved EGFR- and VEGFR-targeted agents and immunotherapies for the second-line treatment of patients with $\mathrm{SqCC}$ of the lung

\begin{tabular}{|c|c|c|c|c|c|}
\hline Therapy type & Trial & Patient population & Treatment arms & $\begin{array}{l}\text { Efficacy (OS and PFS) in } \\
\text { SqCC }\end{array}$ & Reference \\
\hline \multirow[t]{4}{*}{ Immunotherapies } & $\begin{array}{l}\text { Checkmate-0I7; } \\
\text { Phase III }\end{array}$ & $\begin{array}{l}\text { Metastatic SqCC of } \\
\text { the lung }(\mathrm{N}=272) \text {; } \\
\text { progression during or } \\
\text { after platinum-based } \\
\text { chemotherapy; six Asian } \\
\text { pts }(2 \%)\end{array}$ & $\begin{array}{l}\text { Nivolumab vs } \\
\text { docetaxel }\end{array}$ & $\begin{array}{l}\text { Significant } \mathrm{OS} \text { and } \mathrm{PFS} \\
\text { improvement: } 9.2 \text { vs } 6.0 \text { months } \\
(\mathrm{HR}=0.59,95 \% \mathrm{Cl}=0.4-0.8 ; \\
P<0.00 \mathrm{I}) \text { median } \mathrm{PFS} 3.5 \text { vs } \\
2.8 \text { months }(\mathrm{HR}=0.62,95 \% \\
\mathrm{Cl}=0.5-0.8 ; P<0.00 \mathrm{I}) ; \text { Asian } \\
\text { subset data not reported }\end{array}$ & 69 \\
\hline & $\begin{array}{l}\text { Keynote-0I0; } \\
\text { Phase II/III }\end{array}$ & $\begin{array}{l}\text { Previously treated, } \\
\text { PD-LI-positive, advanced } \\
\text { NSCLC; } 222 \text { pts with } \\
\text { SqCC of the lung ( } 21 \%) ; \\
217 \text { Asian pts }(21 \%)\end{array}$ & $\begin{array}{l}\text { Pembrolizumab vs } \\
\text { docetaxel }\end{array}$ & $\begin{array}{l}\text { Trend for benefit in patients } \\
\text { with } \mathrm{SqCC} \text { of the lung; OS } \\
(\mathrm{HR}=0.74,95 \% \mathrm{Cl}=0.5-\mathrm{I} . \mathrm{I}) \text {; } \\
\mathrm{PFS}(\mathrm{HR}=0.86,95 \% \\
\mathrm{Cl}=0.6-1.2) \text {; Asian subset data } \\
\text { not reported }\end{array}$ & 71 \\
\hline & POPLAR Phase II & $\begin{array}{l}\text { Previously treated } \\
\text { NSCLC; } 97(34 \%) \\
\text { SqCC of the lung; no } \\
\text { information on ethnicity }\end{array}$ & $\begin{array}{l}\text { Atezolizumab vs } \\
\text { docetaxel }\end{array}$ & $\begin{array}{l}\text { OS significantly improved: } 10.1 \\
\text { vs } 8.6 \text { months; (HR }=0.8,95 \% \\
\mathrm{Cl}=0.5-1.3) \text {; PFS not reported }\end{array}$ & 73 \\
\hline & OAK Phase III & $\begin{array}{l}\text { Previously treated } \\
\text { NSCLC; } 222(26 \%) \text { SqCC } \\
\text { of the lung; } 180(21 \%) \\
\text { Asian pts }\end{array}$ & $\begin{array}{l}\text { Atezolizumab vs } \\
\text { docetaxel }\end{array}$ & $\begin{array}{l}\text { OS trend for improvement: } 8.9 \\
\text { vs } 7.7 \text { months; }(\mathrm{HR}=0.73,95 \% \\
\mathrm{Cl}=0.5-1.08, P=0.0038) ; \mathrm{PFS} \\
\text { not reported; Asian subset data } \\
\text { not reported }\end{array}$ & 74 \\
\hline $\begin{array}{l}\text { VEGFR-targeted } \\
\text { agents }\end{array}$ & REVEL Phase III & $\begin{array}{l}\text { Stage IV NSCLC after } \\
\text { platinum-based therapy; } \\
328 \text { pts (26\%) SqCC of } \\
\text { the lung; } 89(7 \%) \text { East } \\
\text { Asian pts }\end{array}$ & $\begin{array}{l}\text { Ramucirumab plus } \\
\text { docetaxel vs placebo } \\
\text { plus docetaxel }\end{array}$ & $\begin{array}{l}\text { Median OS } 9.5 \text { vs } 8.2 \text { months } \\
(\mathrm{HR}=0.88,95 \% \mathrm{Cl}=0.7-\mathrm{I} . \mathrm{I}) \text {; } \\
\text { trend for benefit in East Asian } \\
\text { patients; PFS for subgroups not } \\
\text { reported }\end{array}$ & 77 \\
\hline
\end{tabular}


Table 2 (Continued)

\begin{tabular}{|c|c|c|c|c|c|}
\hline Therapy type & Trial & Patient population & Treatment arms & $\begin{array}{l}\text { Efficacy (OS and PFS) in } \\
\text { SqCC }\end{array}$ & Reference \\
\hline \multirow[t]{5}{*}{ EGFR-targeted agents } & BR.2I; Phase III & $\begin{array}{l}\text { NSCLC; progressed } \\
\text { after first-/second-line } \\
\text { chemotherapy; } 222 \text { pts } \\
\text { ( } 38 \%) \text { SqCC of the lung; } \\
42(7 \%) \text { Asian pts }\end{array}$ & Erlotinib vs placebo & $\begin{array}{l}\text { Favorable OS and PFS } \\
\text { outcomes; median OS } 5.6 \text { vs } \\
3.6 \text { months ( } \mathrm{HR}=0.60,95 \% \\
\mathrm{Cl}=0.4-0.8) ; \text { median PFS } 2.3 \\
\text { vs } 1.8 \text { months ( } \mathrm{HR}=0.48,95 \% \\
\mathrm{Cl}=0.4-0.7) ; \text { no data reported } \\
\text { for Asian subgroup }\end{array}$ & 43,44 \\
\hline & TAILOR Phase III & $\begin{array}{l}\text { NSCLC; WT EGFR; } \\
\text { prior platinum-based } \\
\text { chemotherapy; } 54 \text { pts } \\
\text { (25\%); two (1\%) } \\
\text { Asian pts }\end{array}$ & Erlotinib vs docetaxel & $\begin{array}{l}\text { OS and } \mathrm{PFS} \text { in } \mathrm{SqCC} \text { of the } \\
\text { lung favor docetaxel, but } \\
\text { no significant difference: } \mathrm{OS} \\
(\mathrm{HR}=0.90,95 \% \mathrm{Cl}=0.5-1.7 \\
P=0 . \mathrm{I} 4) ; \mathrm{PFS}(\mathrm{HR}=0.57,95 \% \\
\mathrm{Cl}=0.3-\mathrm{I} .0 ; \mathrm{P}=0.3) \text {; no data } \\
\text { reported for Asian pts }\end{array}$ & 45 \\
\hline & $\begin{array}{l}\text { LUX-Lung 8; } \\
\text { Phase III }\end{array}$ & $\begin{array}{l}\mathrm{SqCC} \text { of the lung } \\
\text { ( } \mathrm{N}=795) ; \text { progression } \\
\text { after } \geq 4 \text { cycles } \\
\text { of platinum-based } \\
\text { chemotherapy; } 67 \text { (8.4\%) } \\
\text { Chinese pts }\end{array}$ & Afatinib vs erlotinib &  & 41,50 \\
\hline & $\begin{array}{l}\text { LUX-Lung 5; } \\
\text { Phase III }\end{array}$ & $\begin{array}{l}\text { NSCLC progressed } \\
\text { on chemotherapy and } \\
\text { erlotinib/gefitinib; part A: } \\
91 \text { ( } 8 \%) \mathrm{SqCC} \text { of the lung }\end{array}$ & $\begin{array}{l}\text { Part A: afatinib } \\
\text { monotherapy }\end{array}$ & Median PFS 3.7 months & 55 \\
\hline & & $\begin{array}{l}\text { Part B: I7 (8.4\%) SqCC } \\
\text { of the lung; } 82(41 \%) \text { East } \\
\text { Asian pts }\end{array}$ & $\begin{array}{l}\text { Part B: Afatinib plus } \\
\text { paclitaxel (for pts } \\
\text { progressing on afatinib } \\
\text { following clinical } \\
\text { benefit in part A) }\end{array}$ & $\begin{array}{l}\text { Median PFS } 5.6 \text { months; PFS } \\
(\mathrm{HR}=0.15,95 \% \mathrm{Cl}=0.0-0.6) \\
\text { vs adenocarcinoma; East Asian } \\
(\mathrm{HR}=0.67,95 \% \mathrm{Cl}=0.4-1.2) \text { vs } \\
\text { Caucasian pts }\end{array}$ & 86 \\
\hline
\end{tabular}

Abbreviations: NSCLC, non-small-cell lung cancer; OS, overall survival; PD-LI, programmed death ligand-I; PFS, progression-free survival; pts, patients; SqCC, squamous cell carcinoma; VEGFR, vascular endothelial growth factor receptor; WT, wild-type.

inactivate aberrant ErbB-dependent signaling cascades and, therefore, be effective in patients with SqCC of the lung. ${ }^{41,50}$

\section{LUX-Lung 8: afatinib vs erlotinib as the second-line treatment for $\mathrm{SqCC}$ of the lung}

The LUX-Lung 8 trial was an open-label, randomized Phase III trial that compared afatinib (40 mg/day) with erlotinib (150 mg/day) in 795 patients with relapsed/refractory stage IIIB/IV SqCC of the lung who had progressed on or after platinum-based chemotherapy. ${ }^{41}$ Afatinib significantly improved progression-free survival (PFS; primary endpoint) and OS (key secondary endpoint) vs erlotinib (median PFS $=2.6$ vs 1.9 months, respectively $[\mathrm{HR}=0.82,95 \%$ $\mathrm{CI}=0.68-1.00] ; P=0.0103$; median $\mathrm{OS}=7.9$ vs 6.8 months, respectively $[\mathrm{HR}=0.81,95 \% \mathrm{CI}=0.69-0.95] ; P=0.0077$; Figure $3 \mathrm{~A}$ and B). ${ }^{41}$ Disease control rate (DCR) was also significantly higher with afatinib than with erlotinib $(51 \%$ vs $40 \% ; P=0.002) .{ }^{41}$ Based on these data (Table 2), afatinib gained US approval in 2016 for the treatment of locally 
A

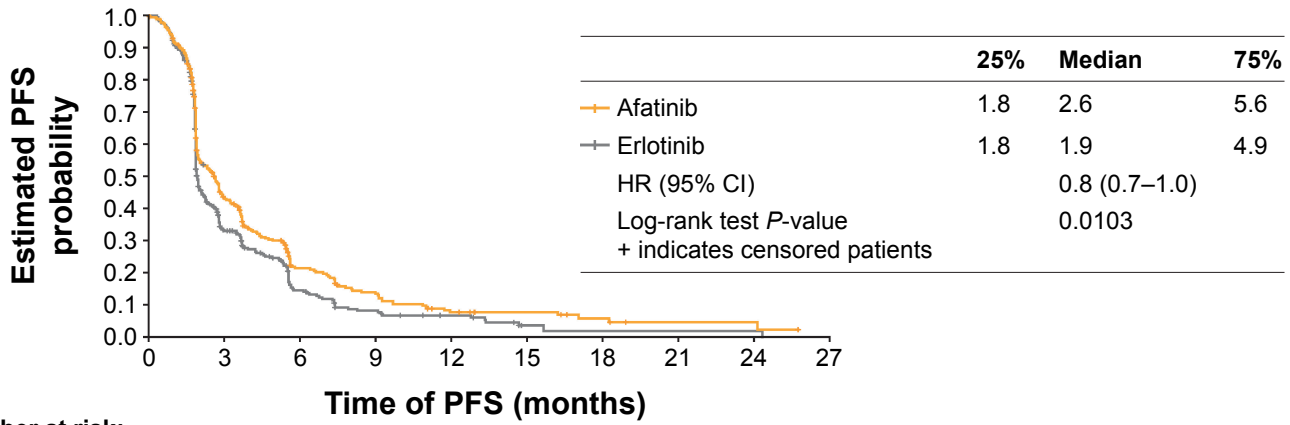

Number at risk:

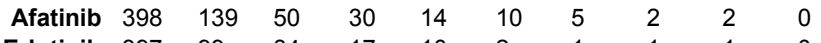

$\begin{array}{lllllllllll}\text { Erlotinib } & 397 & 99 & 34 & 17 & 10 & 2 & 1 & 1 & 1 & 0\end{array}$

B

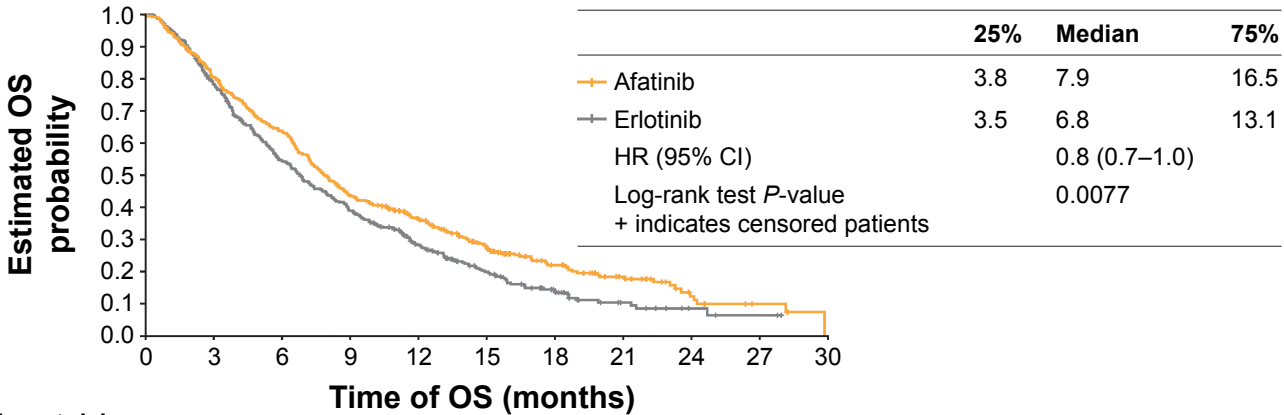

Number at risk:

$\begin{array}{rlllllllllll}\text { Afatinib } & 398 & 316 & 249 & 170 & 124 & 82 & 47 & 28 & 10 & 4 & 0 \\ \text { Erlotinib } & 397 & 305 & 210 & 150 & 94 & 54 & 30 & 11 & 4 & 2 & 0\end{array}$

C

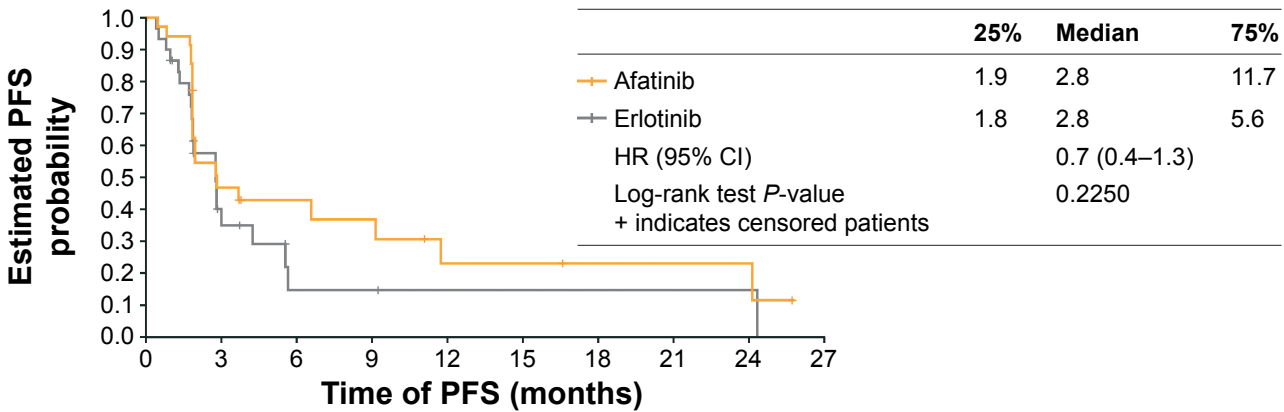

Number at risk:

$\begin{array}{ccccccccccc}\text { Afatinib } & 36 & 12 & 7 & 6 & 3 & 3 & 2 & 2 & 2 & 0 \\ \text { Erlotinib } & 31 & 7 & 2 & 2 & 1 & 1 & 1 & 1 & 1 & 0\end{array}$

D

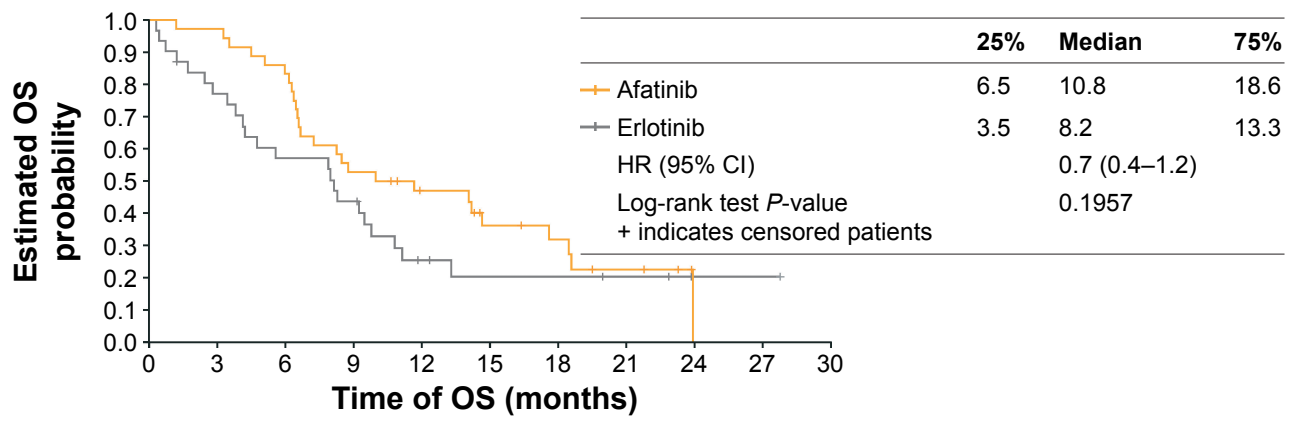

Number at risk:

$\begin{array}{cccccccccccc}\text { Afatinib } & 36 & 35 & 31 & 19 & 14 & 9 & 7 & 4 & 0 & 0 & 0 \\ \text { Erlotinib } & 31 & 23 & 17 & 13 & 6 & 4 & 4 & 3 & 1 & 1 & 0\end{array}$

Figure 3 LUX-Lung 8: Kaplan-Meier plots for overall study population vs Chinese subgroup. (A) PFS (an independent review) and (B) OS for the overall treatment population; (A and B) Reprinted from Soria JC, Felip E, Cobo M, et al. Afatinib versus erlotinib as second-line treatment of patients with advanced squamous cell carcinoma of the lung (LUX-Lung 8): an open-label randomised controlled phase 3 trial, Lancet Oncol. 2015;16(8):897-907. Copyright (C) 2015, with permission from Elsevier. ${ }^{41}$ (C) PFS (an independent review) and (D) OS for the Chinese subgroup (C and D) Copyright @2013. Dove Medical Press. Republished from Lu S, Li W, Zhou C, et al. Afatinib versus erlotinib for second-line treatment of Chinese patients with advanced squamous cell carcinoma of the lung: a subgroup analysis of the phase 3 LUX-Lung 8 trial. Onco Targets Ther. 2018;1 I:8565-8573..$^{50}$

Abbreviations: OS, overall survival; PFS, progression-free survival. 
advanced or metastatic SqCC of the lung progressing on or after platinum-based chemotherapy. ${ }^{14}$

Of the 795 patients enrolled in the LUX-Lung 8 trial, $67(8.4 \%)$ patients were from Mainland China. ${ }^{50}$ Of these, 36 patients were randomized to receive afatinib and 31 patients to receive erlotinib. ${ }^{50}$ Although this exploratory analysis was not powered to show significant differences between treatment groups, improvements in the Chinese subset were comparable to those in the overall treatment population (OTP). ${ }^{50}$ There were more patients who had a long-term response in the Chinese subgroup than in the OTP (11\% vs 5\%), with a median treatment duration of 22.7 vs 17.6 months, respectively. ${ }^{50,51}$ While median PFS was similar in Chinese patients who received afatinib and erlotinib (2.8 months in both the groups; $\mathrm{HR}=0.70$; Figure $3 \mathrm{C}$ ), there was a trend toward prolonged OS with afatinib compared with erlotinib (10.8 vs 8.2 months; HR $=0.7$; Figure 3D).$^{50}$ Overall response rates were improved with afatinib vs erlotinib in the Chinese subgroup, although the difference was not statistically significant. DCR was comparable between the two groups. ${ }^{50}$ These data suggest that afatinib is a viable treatment option for Chinese patients with advanced SqCC of the lung.

Afatinib significantly improved patient-reported outcomes vs erlotinib in both the OTP and Chinese subgroups. ${ }^{41}$ Many Chinese patients reported an improved global health status/quality of life (QoL; $52.8 \%$ afatinib vs $29.6 \%$ erlotinib; $P=0.072)$ compared with the OTP (36\% afatinib vs $28 \%$ erlotinib; $P=0.041) .{ }^{41,50,52}$ In the Chinese subgroup, "dyspnea walked" (shortness of breath while walking), time to deterioration of cough, and QoL rates were significantly improved, and time to deterioration of cough was significantly delayed with afatinib vs erlotinib. ${ }^{50,52}$ Health-related QoL is an important consideration in the choice of appropriate treatments for patients with lung cancer. These data indicate that afatinib may improve health-related QoL outcomes in Chinese patients.

Afatinib demonstrated a predictable and manageable safety profile in patients with SqCC of the lung, ${ }^{41}$ similar to that observed in the LUX-Lung 3 and LUX-Lung 6 trials $^{20,21}$ and consistent with the mechanistic profile of ErbB inhibition. In the OTP, the few discontinuations due to AEs, including the common class-related AEs of diarrhea (4\%) and rash or acne $(3 \%)$, suggested that the well-established recommended dose-adjustment schemes and supportive care measures enabled patients to remain on afatinib treatment for as long as they get a clinical benefit. ${ }^{14,41,53}$ Among Chinese patients, the tolerability profile of afatinib was consistent with that observed in the OTP. ${ }^{50}$ In the Chinese subgroup, there were no cases of grade $\geq 3$ diarrhea, and none of the patients discontinued treatment due to afatinib-related diarrhea, ${ }^{50}$ which indicates that afatinib is well tolerated in Chinese patients. Overall, the LUX-Lung 8 trial data support afatinib as an effective and well-tolerated treatment option for Chinese patients with advanced SqCC of the lung.

In addition to the findings from LUX-Lung 8 , because most patients in the LUX-Lung 3 trial $^{20}$ and all patients in the LUX-Lung 6 trial $^{21}$ were East Asian, it can be concluded that the safety profile of afatinib in East Asian patients is predictable and manageable. Afatinib has recently been approved in China, for treating both advanced NSCLC and SqCC of the lung. ${ }^{54}$

Other clinical studies have provided evidence of the activity of afatinib in patients with squamous tumors. In part A of the Phase III LUX-Lung 5 trial, patients with NSCLC who had progressed on chemotherapy and erlotinib/gefitinib after initial disease control received afatinib monotherapy (50 mg/day). ${ }^{55}$ In a subanalysis of 91 patients with SqCC of the lung, the DCR was $60 \%$ and the median PFS was 3.7 months. ${ }^{12,55}$

Similar to SqCC of the lung, other tumors with squamous histology, such as head and neck cancer, often show a high EGFR expression and/or an increased EGFR gene copy number and a low incidence of activating kinase domain mutations. In the Phase III LUX-Head and Neck 1 trial, afatinib monotherapy (40 mg/day) prolonged PFS vs methotrexate in patients with recurrent/metastatic head and neck SqCC. ${ }^{56}$ In addition, in a recent Phase II study, the use of afatinib (40 mg/day) preoperatively led to an improved response compared with no treatment (NT) in patients with untreated head and neck SqCC. ${ }^{57}$ Progressive disease (PD) occurred in $16.6 \%$ of the NT arm, whereas none of the patients receiving afatinib had $\mathrm{PD}$. There were significantly more partial responses in the afatinib group (48\%) than in the NT group ( $7 \% ; P=0.005)$, as measured by PET-computed tomography scan, using PET Response Criteria in Solid Tumors. ${ }^{57}$

\section{Emerging ErbB overexpression and mutation biomarker data for SqCC of the lung}

SqCC of the lung is genetically complex, ${ }^{34,41,46,58}$ and the identification of predictive biomarkers may help to establish the optimal second-line treatment. ${ }^{59}$ Although EGFRactivating mutations are rare, the cumulative frequency of ErbB mutations is much higher, $\sim 1 \%-4 \%, 1 \%-2 \%$, and $1 \%-2 \%$ for EGFR, ErbB2, and ErbB3, respectively. ${ }^{34,60-62}$ A comprehensive analysis of squamous cell tumors identified genetic aberrations in several signaling molecules downstream of the ErbB receptors: KRAS, HRAS, BRAF, 
RASA1, NF1, and NRG1. ${ }^{12,46,60}$ Reported differences between the incidences of specific mutations (including EGFR and ErbB2) between Western and Asian patients (Table 1) underpin the need to study targeted therapies in different ethnic groups. ${ }^{34}$ Given these findings in SqCC and the fact that SqCCs overexpress EGFR and other ErbB family proteins, ${ }^{36-38,61}$ the analysis of the ErbB family was prespecified in the LUX-Lung 8 trial.

\section{ErbB family mutation and EGFR overexpression analysis in LUX-Lung 8}

By using a next-generation sequencing-based gene assay, ${ }^{63}$ tumor genetic analysis (TGA) was conducted on tumor samples from 245 patients in the LUX-Lung 8 trial. ${ }^{61}$ The most frequently observed genetic aberrations in the TGA cohort were single-nucleotide variations in TP53 $(87.3 \%$ of patients), LRP1B (39.2\%), MLL2 (33.1\%), CDKN2A (28.6\%), and FAT3 (27.3\%) and copy number alterations in SOX2 (42.9\%), KLHL6 (39.6\%), PIK3CA (36.3\%), MAP3K13 (32.2\%), BCL6 (30.6\%), and FGF12 (28.2\%). ${ }^{61}$ The findings are similar to those of the Cancer Genome Atlas Research Network study in SqCC of the lung. ${ }^{46,61}$ None of the most frequently observed aberrations predicted clinical outcomes, ${ }^{61}$ but by focusing on ErbB family mutations, some interesting trends emerged. In total, $21.6 \%$ of patients in the TGA subset had at least one ErbB family singlenucleotide variant mutation (Figure 4). ${ }^{61}$ In the overall data set, 21 patients $(5.3 \%)$ were long-term responders (LTRs) to afatinib (received $\geq 12$ months of treatment), ten of these were included in the TGA cohort, and five (50.0\%) had ErbB mutations. ${ }^{61}$ Among patients treated with afatinib (but not with erlotinib), PFS and OS were longer in those with vs without ErbB mutations (PFS $=4.9$ vs 3.0 months, $\mathrm{OS}=10.6$ vs 8.1 months for afatinib; PFS $=2.7$ vs 2.4 months, $\mathrm{OS}=7.2$ vs 6.4 months for erlotinib; Figure 5). ${ }^{61}$ In the OTP for the LUX-Lung 8 trial, frequencies of EGFR mutation-positive tumors were low in both the treatment groups $(6.8 \%$ afatinib vs $6.2 \%$ erlotinib). ${ }^{50,61}$ Mutations in EGFR, in isolation, did not predict any clinical benefit with afatinib over erlotinib. ${ }^{61}$ This indicates that clinical outcomes with afatinib vs erlotinib are unlikely to be driven by imbalances in EGFR mutations in the study groups. ${ }^{41,50}$ By contrast, mutations in ErbB3, ErbB4, and in particular ErbB2 seem to drive the benefit of afatinib as compared with erlotinib. ${ }^{61}$ In patients with an ErbB2 mutation (12 of $245 ; 4.9 \%$ ), PFS (HR $=0.06,95 \%$ $\mathrm{CI}=0.01-0.59)$ and $\mathrm{OS}(\mathrm{HR}=0.06,95 \% \mathrm{CI}=0.01-0.57)$ strongly favored afatinib vs erlotinib. Despite the small sample size, the interaction $P$-value $\left(P_{\text {int }}\right)$ was significant for both PFS $\left(P_{i n t}=0.006\right)$ and OS $\left(P_{i n t}=0.003\right)$, indicating that the presence of an ErbB2 mutation may predict better clinical outcomes with afatinib vs erlotinib in patients with SqCC of the lung. ${ }^{61}$ Data on ErbB mutations were not available for the Chinese population included in LUX-Lung 8 trial. Further investigation into the impact of ErbB family

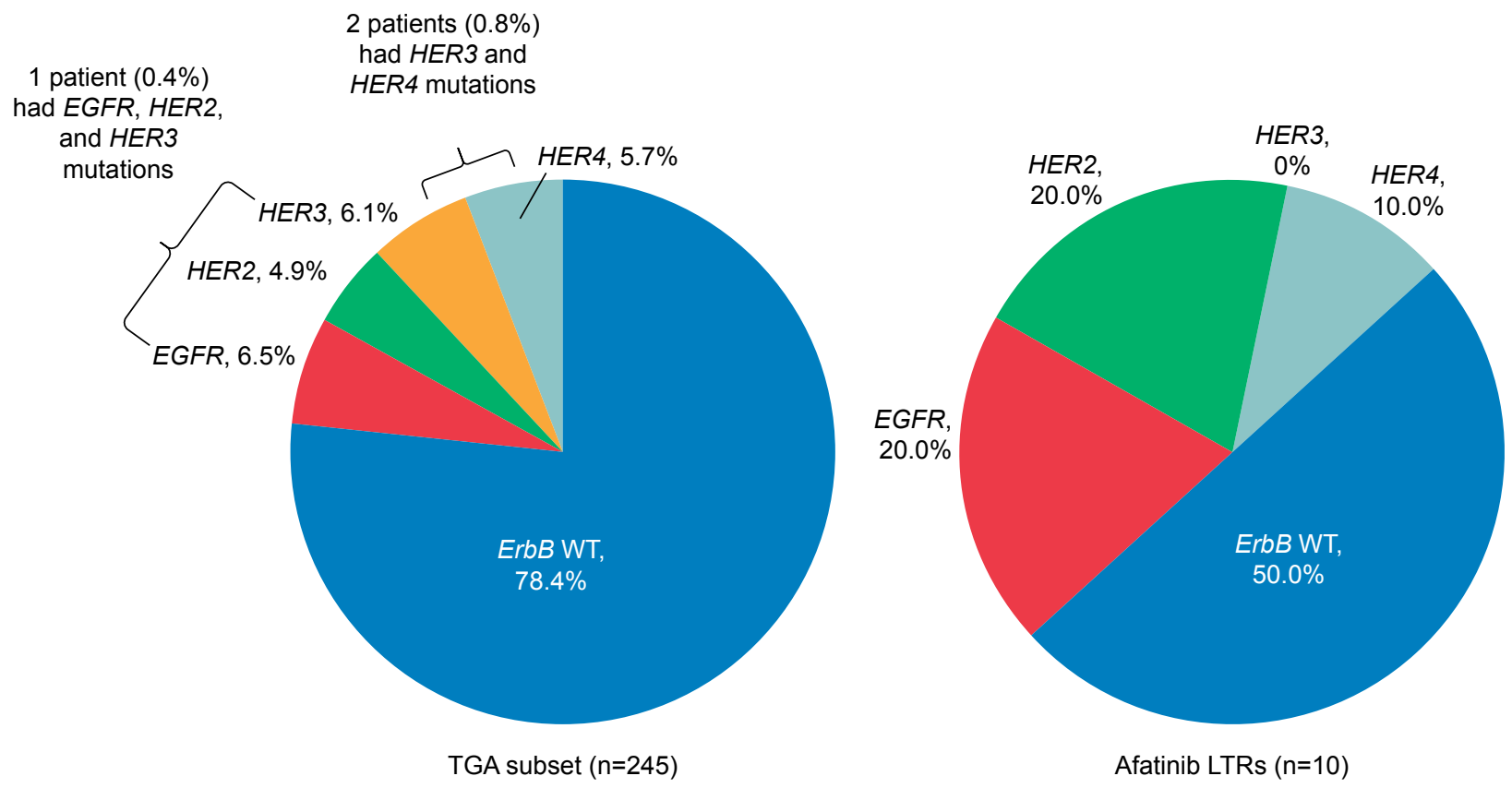

Figure 4 LUX-Lung 8: frequency of ErbB family mutations in the overall TGA cohort and in patients who were LTRs to afatinib.*61

Note: *There were three LTRs to erlotinib (one had a tumor with an EGFR mutation and two had tumors which were EGFR WT).

Abbreviations: LTRs, long-term responders; TGA, tumor genetic analysis; WT, wild-type. 
A

\begin{tabular}{llllll}
\cline { 3 - 6 } \\
\end{tabular}

Number at risk:

Afatinib: Absent 107

Afatinib: Present 25

Erlotinib: Absent 85

Erlotinib: Present 28

$\begin{array}{llll}47 & 15 & 8 & 3 \\ 16 & 8 & 6 & 4 \\ 26 & 5 & 2 & 2 \\ 9 & 4 & 1 & 0\end{array}$

B

\begin{tabular}{llllll}
\cline { 3 - 5 } \\
\end{tabular}

Number at risk:

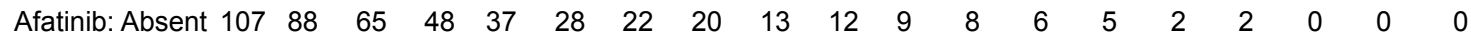

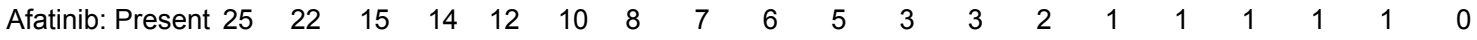

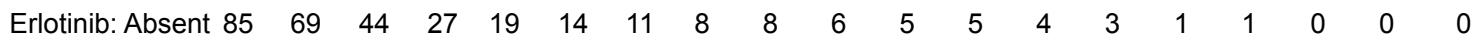

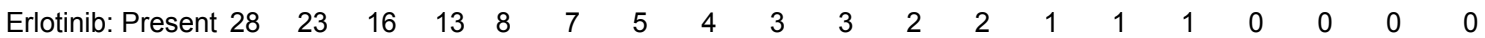

Figure 5 Comparison of (A) PFS and (B) OS between patients with the presence or the absence of ErbB family mutations.

Note: Reproduced with permission from Goss GD, Felip E, Cobo M, et al. Association of ERBB mutations with clinical outcomes of afatinib- or erlotinib-treated patients with lung squamous cell carcinoma: secondary analysis of the LUX-Lung 8 randomized clinical trial. JAMA Oncol. 2018;4(9):I 189-II97. Copyright@2018 American Medical Association. ${ }^{61}$ Abbreviations: OS, overall survival; PFS, progression-free survival. 
mutations on clinical outcomes with afatinib in this patient population is warranted.

EGFR expression was assessed by immunohistochemistry in 345 tumor samples from the OTP of LUX-Lung 8 (apart from 11 patients, this population was different to that used for TGA). ${ }^{61}$ High levels of EGFR overexpression (defined as an $\mathrm{H}$-score $\geq 200$ ) were observed: 45 of 157 (28.7\%) afatinib-treated patients and 72 of 188 (38.3\%) erlotinib-treated patients had EGFR overexpression. ${ }^{61}$ EGFR overexpression did not predict a PFS or an OS benefit with afatinib vs erlotinib, suggesting that the efficacy of afatinib is not driven by EGFR overexpression in this patient group. EGFR overexpression was also assessed in 60 Chinese patients in the LUX-Lung 8 trial. In total, 19\% of Chinese patients treated with afatinib and $25 \%$ treated with erlotinib had EGFR overexpression, which is similar to the frequency observed in the OTP. ${ }^{50,61}$ Similarly, EGFR overexpression was not predictive of survival benefit with afatinib over erlotinib in the Chinese patients..$^{50,61}$

In conclusion, a subgroup of patients with ErbB mutations may particularly benefit from afatinib treatment. This difference could be due to the broad mechanism of action of afatinib and the irreversible inhibition of signaling via all ErbB dimers. Mutations in ErbB members, particularly ErbB2, may be useful as predictive biomarkers for afatinib in this setting.

\section{ErbB family protein-specific blood-based assay in the LUX-Lung 8 trial}

Another approach that could help differentiate subgroups of patients with $\mathrm{SqCC}$ of the lung who would benefit from specific second-line therapies is the use of a blood-based protein assay. The VeriStrat ${ }^{\circledR}$ test was developed for EGFR wild-type NSCLC or unknown mutation status. It uses matrix-laser desorption ionization mass spectrometry to analyze patients' pretreatment serum and compares the mass spectra obtained with a reference set. The classification as VeriStrat-good (VS-G) or VeriStratpoor (VS-P) predicts good or poor survival, respectively, on EGFR TKIs. ${ }^{64}$ This test has demonstrated a prognostic and predictive value in NSCLC for erlotinib. ${ }^{65,66}$

In a retrospective analysis of the LUX-Lung 8 trial, the ability of the VeriStrat ${ }^{\circledR}$ test to predict clinical benefit with afatinib vs erlotinib was investigated (Figure 6). ${ }^{59}$ In the OTP, 675 of the 795 patients were classified, 412 as VS-G and 263 as VS-P. ${ }^{59}$ Furthermore, $14.4 \%$ of the 675 VeriStratclassified patients and $21.6 \%$ of the 795 patients in the OTP were East Asian.

In the VS-G group, OS was significantly longer with afatinib vs erlotinib (11.5 months on afatinib vs 8.9 months; $\mathrm{HR}=0.79,95 \% \mathrm{CI}=0.63-0.98)$, indicating that afatinib is a valuable second-line option in this patient group. ${ }^{59}$ In the VS-P group, there was no significant difference in OS between afatinib and erlotinib (HR $=0.90,95 \% \mathrm{CI}=0.70-1.16) .{ }^{59} \mathrm{How}-$ ever, there was no interaction between VeriStrat classification and treatment group for OS $\left(P_{\text {int }}=0.5303\right)$. The authors suggested that this may be due to the relatively small sample size and therefore broad $95 \%$ CIs of the VS-P group. ${ }^{59}$ OS was significantly longer in VS-G than in VS-P patients, both for the overall VeriStrat-classified population $(\mathrm{HR}=0.41,95 \% \mathrm{CI}$ $=0.35-0.49)$ and for the afatinib-treated patients $(\mathrm{HR}=0.40$, $95 \% \mathrm{CI}=0.31-0.51) .{ }^{59}$ In the overall VeriStrat-classified population, $15 \%$ of VS-G and $13.3 \%$ of VS-P patients were from East Asia. ${ }^{59}$ No further analysis was conducted on the Eastern Asian subgroup. The multivariate analysis showed that VeriStrat classification was an independent predictor of OS in afatinib-treated patients, regardless of race, performance status, or best response to the first-line chemotherapy. ${ }^{59}$

In conclusion, VS-G classification is strongly associated with favorable survival outcomes with either afatinib or erlotinib compared with VS-P classification. Patients who are classified as VS-G by the proteomic test derive a greater OS benefit from afatinib than from erlotinib. VeriStrat classification should therefore be considered when guiding in treatment decision-making in patients with $\mathrm{SqCC}$ of the lung.

\section{Biomarkers of long-term response in the LUX-Lung 8 trial}

Clinical and molecular biomarkers indicative of long-term response ( $\geq 12$ months' afatinib treatment) were explored in the LUX-Lung 8 trial. ${ }^{51}$ There were 21 LTRs (5\%) in the afatinib treatment group ( $\mathrm{N}=398$; Figure 7$)$; the median OS in the LTRs was 21.2 months. Fifteen of the 17 LTRs evaluated using the VeriStrat test (88\%) were classified as VS-G. ${ }^{51}$ None of the LTRs was East Asian.

The mutation profile of LTRs showed increased ErbB2, ErbB4, and EGFR mutations compared with the overall afatinib-treated population. ${ }^{51}$ Long-term treatment with afatinib was well tolerated, with an AE profile similar to that of the overall afatinib-treated population. The findings from this analysis suggest that VS-G status and ErbB family mutations may be potential biomarkers of long-term response to afatinib.

\section{Immunotherapies and angiogenesis inhibitors for the treatment of SqCC of the lung Immunotherapies}

The overexpression of the immune checkpoint molecules, programmed cell death protein-1 (PD-1) and/or programmed 
A

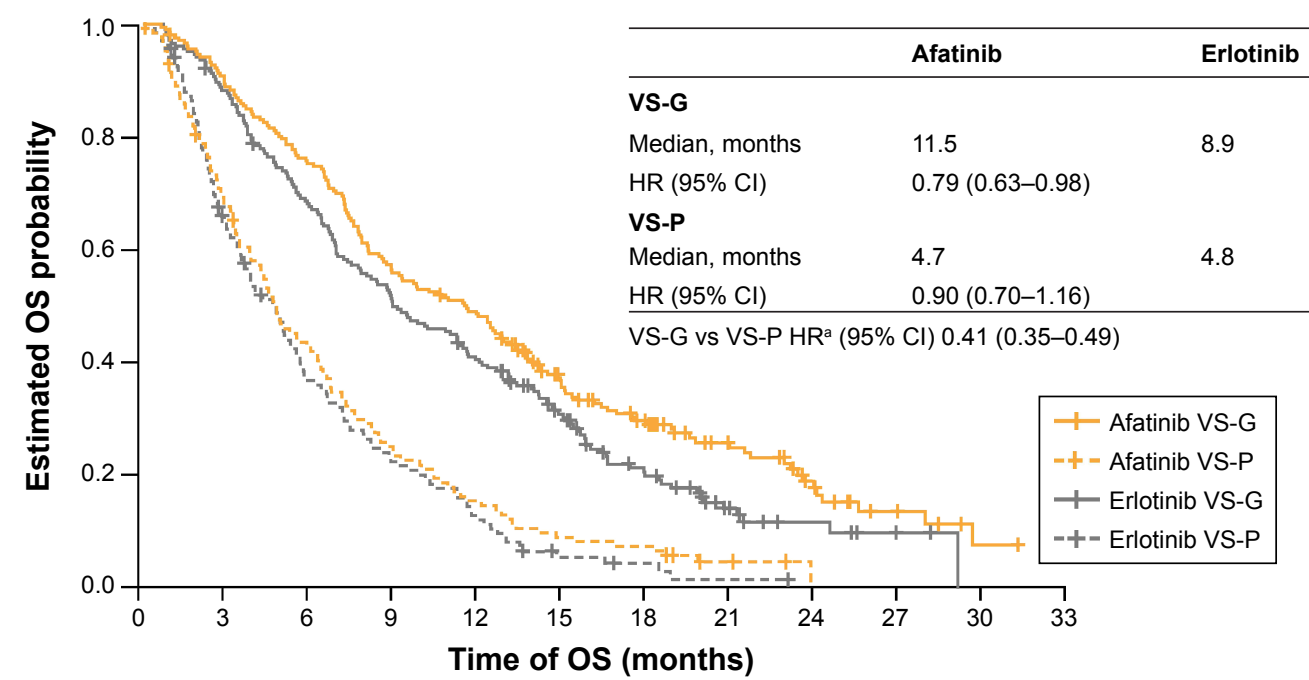

Number at risk:

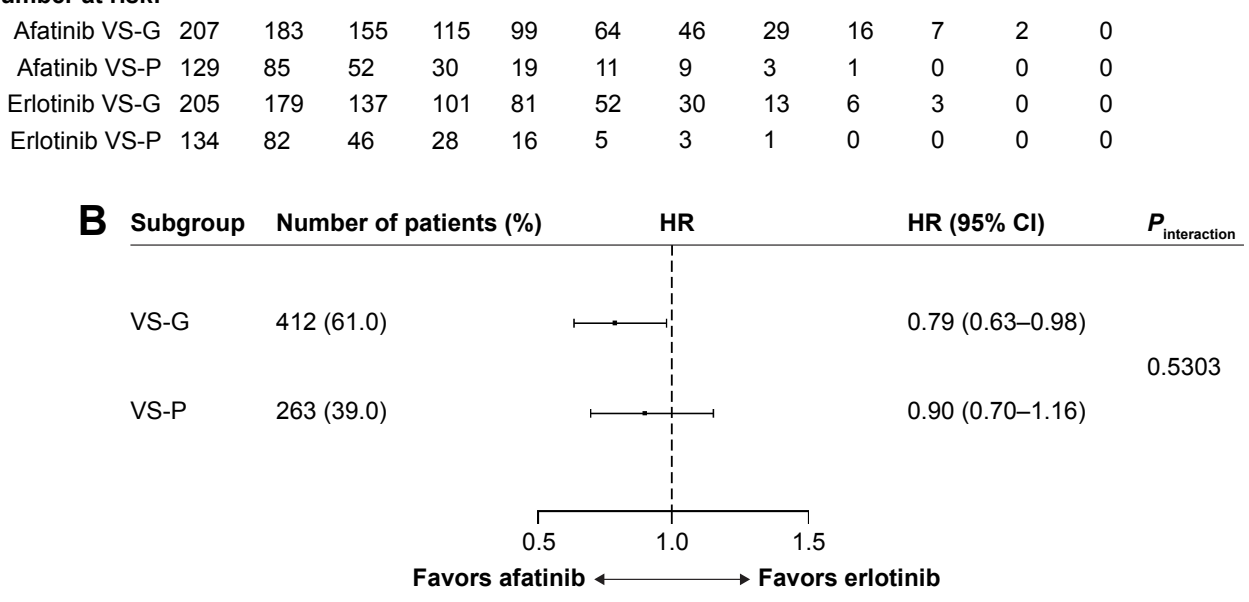

C

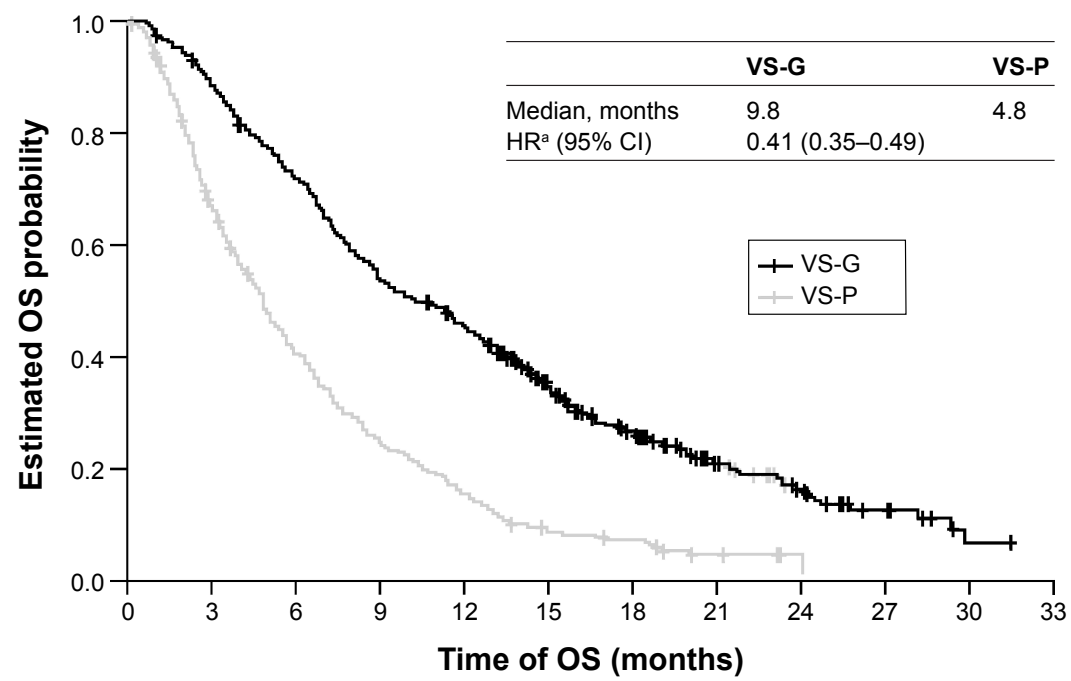

Number at risk:

$\begin{array}{lllllllllllll}\text { VS-G } & 412 & 362 & 292 & 216 & 180 & 116 & 76 & 42 & 22 & 10 & 2 & 0 \\ \text { VS-P } & 263 & 167 & 98 & 58 & 35 & 16 & 12 & 4 & 1 & 0 & 0 & 0\end{array}$

Figure 6 LUX-Lung 8: relationship between VeriStrat classification, OS, and treatment group. (A) Kaplan-Meier curves of OS with afatinib vs erlotinib treatment and VS-G vs VS-P classification; (B) forest plot of OS by treatment group and VeriStrat classification; (C) relationship between VeriStrat classification and OS in all patients.

Notes: ${ }^{2}$ Adjusted for treatment effect. This Figure was published in Lung Cancer. 20I7;109:10I-108, Gadgeel S, Goss G, Soria JC, et al. Evaluation of the VeriStrat ${ }^{\circ}$ serum protein test in patients with advanced squamous cell carcinoma of the lung treated with second-line afatinib or erlotinib in the phase III LUX-Lung 8 study. Copyright $@ 20$ I 7 Elsevier. ${ }^{59}$

Abbreviations: OS, overall survival; VS-G, VeriStrat-good; VS-P, VeriStrat-poor. 


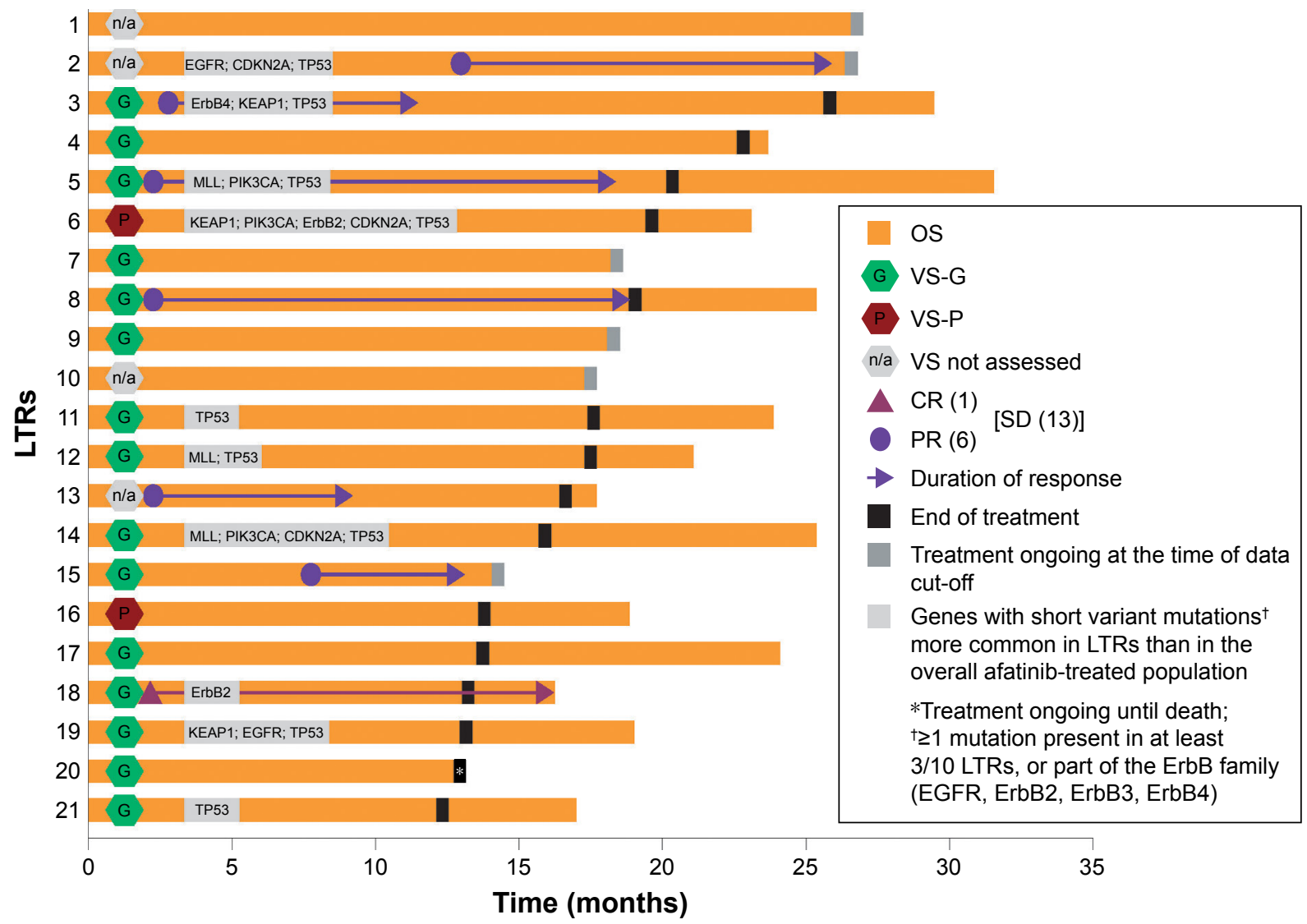

Figure 7 LUX-Lung 8: clinical outcomes, VeriStrat status, and biomarker frequency and biomarkers more commonly observed in LTRs than in the overall trial population. ${ }^{51}$ Abbreviations: CR, complete response; LTRs, long-term responders; n/a, not assessed; OS, overall survival; PR, partial response; SD, stable disease; VS-G, VeriStrat-good; VS-P, VeriStrat-poor.

cell death ligand-1 (PD-L1), enables tumor cells to evade detection and destruction by the immune system. ${ }^{67}$ Immune escape has been shown to be an important feature in the development of SqCC of the lung. ${ }^{68}$

The Food and Drug administration (FDA)-approved immune checkpoint inhibitors for $\mathrm{SqCC}$ of the lung are nivolumab and pembrolizumab (both PD-1 inhibitors) and atezolizumab (a PD-L1 inhibitor; Table 2; Figure 2A). Nivolumab was approved for patients with metastatic SqCC of the lung with progression during or after platinum-based chemotherapy based on data from the Phase III Checkmate-017 trial, in which nivolumab significantly improved OS and PFS compared with docetaxel (see Table 2 for further details). ${ }^{69}$ Only 2\% of the patients in this trial were Asian; therefore, conclusions cannot be drawn regarding the efficacy of nivolumab in the Asian population. ${ }^{69}$ However, data from a small Phase II trial of nivolumab in 35 Japanese patients with advanced or recurrent $\mathrm{SqCC}$ of the lung who had progressed after platinumcontaining chemotherapy indicate that nivolumab may be beneficial in Japanese patients, as OS (a secondary endpoint; 16.3 months; $95 \% \mathrm{CI}=12.4-25.4$ ) was consistent with the results of the Checkmate-017 trial in the Caucasian population. ${ }^{70}$
In the Phase II/III Keynote- 010 trial $^{71}$ in previously treated PD-L1-positive, advanced NSCLC, OS was significantly longer for pembrolizumab than for docetaxel (Table 2). ${ }^{71}$ Unlike nivolumab, pembrolizumab has not been evaluated specifically in patients with SqCC of the lung. However, a trend for clinical benefit was shown with pembrolizumab in the $21 \%$ of patients who had SqCC of the lung, although a subgroup analysis by ethnicity ( $21 \%$ were Asian) was not reported. ${ }^{71}$ The addition of the first-line pembrolizumab to carboplatin plus paclitaxel or nab-paclitaxel was also shown to improve PFS and OS in patients with PD-L1-unselected, treatment-naïve, advanced squamous NSCLC, without adding substantial toxicity. In this study, 19\% of patients were from East Asia, and the benefits of adding pembrolizumab to the chemotherapy regimen in terms of both PFS and OS appeared particularly marked in the East Asian subgroup. ${ }^{72}$

Atezolizumab gained FDA approval based on two randomized clinical trials, POPLAR ${ }^{73}$ and OAK (Table 2). ${ }^{74}$ In the POPLAR trial, $34 \%$ of patients had squamous histology, and a similar improvement in OS was observed in patients with squamous $(\mathrm{HR}=0.80,95 \% \mathrm{CI}=0.49-1.30)$ and nonsquamous histology $(\mathrm{HR}=0.69,95 \% \mathrm{CI}=0.47-1.01) .{ }^{73}$ 
In the Phase III OAK trial, $26 \%$ of the study population had SqCC of the lung. ${ }^{74}$ A similar improvement in OS was observed in patients with squamous (HR $=0.73,95 \%$ $\mathrm{CI}=0.54-0.98 ; P=0.0383)$ and nonsquamous histology $(\mathrm{HR}=0.73,95 \% \mathrm{CI}=0.60-0.89 ; P=0.0015) .{ }^{74}$ While both the POPLAR and OAK trials had study centers in East Asia, the number of Chinese patients included was not disclosed.

The safety profile of immune checkpoint inhibitors is generally favorable; however, they can be associated with immune-related AEs. These include dermatological (eg, rash), gastrointestinal (GI) tract (eg, diarrhea, colitis), hepatic and endocrine AEs, and other less common but potentially life-threatening inflammatory events, such as pneumonitis. ${ }^{75}$ Temporary immunosuppression with corticosteroids is often necessary and helps manage and reverse these AEs. ${ }^{75}$ Infusion-related reactions can occur with intravenous (IV) administration of immune checkpoint inhibitors, which may make them unsuitable for use in elderly patients and difficult to use effectively in areas with poor medical infrastructure.

\section{Angiogenesis inhibitors}

One of the key pathways that stimulate tumor angiogenesis involves the VEGFRs, which initiate signal cascades that trigger angiogenesis. ${ }^{76}$ Ramucirumab is an anti-VEGFR-2 antibody that has been FDA-approved for NSCLC, including SqCC of the lung, when administered with docetaxel, based on superior efficacy shown in the Phase III REVEL trial (Table 2; Figure 2B). ${ }^{77}$ A subgroup analysis conducted to assess outcomes in 89 East Asian patients, $35 \%$ of whom had SqCC of the lung, showed a trend for clinical benefit favoring the ramucirumab-containing regimen. ${ }^{78}$ Due to the increased incidence of neutropenia and febrile neutropenia observed in East Asian patients, the starting dose of docetaxel was amended and reduced in 24 patients enrolled later into the trial. ${ }^{77,78}$ Serious AEs related to the mechanism of action of ramucirumab include hemorrhage, GI perforation, and impaired wound healing. ${ }^{15}$ As with immune checkpoint inhibitors, infusion-related reactions can occur with IV administration of anti-VEGFR inhibitors, so similar precautions and pre-medications are required.

Although these agents have been FDA-approved as the second-line treatment in patients with advanced SqCC of the lung, none of the pivotal trials included patients with $\mathrm{SqCC}$ of the lung from China and only the REVEL trial analyzed data from an Asian population. Consequently, there is a need for additional treatment options to improve the outcomes for patients with SqCC of the lung and also to investigate efficacy and tolerability particularly in Chinese patients.

\section{Future directions in the treatment of SqCC of the lung Global clinical trials of targeted therapies in $\mathrm{SqCC}$ of the lung}

Key areas of the development of targeted therapies in SqCC of the lung include novel immunotherapies and expansion into the first-line treatment, novel combination regimens with immunotherapies, and agents against novel drug targets. Many of the ongoing clinical trials include centers in China (Table 3). The Keynote-407 trial of pembrolizumab plus paclitaxel in first-line SqCC of the lung includes Chinese study centers. Atezolizumab plus platinum-based chemotherapy is also being evaluated in advanced SqCC of the lung, one trial being in China. Other relevant studies in SqCC of the lung (not involving Chinese centers) include a trial of ramucirumab plus platinum-based chemotherapy in previously untreated NSCLC (including SqCC), a trial of afatinib plus pembrolizumab following the progression of $\mathrm{SqCC}$ during/after platinum-based therapy (not yet recruiting), and trials of the PD-L1 inhibitors, avelumab and durvalumab plus tremelimumab. Ipilimumab and tremelimumab (antibodies against CTLA-4) are also being evaluated. The results of a Phase II trial of ipilimumab plus paclitaxel and carboplatin suggested a greater clinical benefit in SqCC than in nonsquamous NSCLC $;{ }^{79}$ this regimen is now being evaluated in Phase III trials, including study centers in China. A regimen comprising ipilimumab and nivolumab is also being evaluated (not in Chinese centers).

To the best of my knowledge, the only EGFR inhibitor in clinical trials specifically for the treatment of SqCC of the lung in China is nimotuzumab (NCT02577341). Nimotuzumab, which is approved for the treatment of head and neck $\mathrm{SqCC}$ in China, is being tested as the first-line and secondline treatments for SqCC of the lung in combination with chemoradiotherapy or chemotherapy. In addition, icotinib, a novel EGFR TKI developed in China, is currently being evaluated in a Phase II trial in China as a monotherapy for the treatment of patients with fully resected-stage IB NSCLC, including SqCC of the lung, harboring an EGFR mutation (NCT02264210).

Other genomic alterations that are therapeutic targets include $P I K 3 C A, F G F R$, and DDR2, which were identified by comprehensive genomic profiling SqCC of the lung. ${ }^{39,46}$ Inhibitors of the proteins encoded by these genes are being investigated in early-phase clinical trials. For example, fibroblast growth factor receptor (FGFR)-1 inhibitors ${ }^{15}$ show a potential activity in SqCC of the lung, with one of three patients with FGFR-expressing SqCC of the lung included 
Table 3 Targeted drugs for SqCC of the lung being investigated in clinical trials in China or including centers in China

\begin{tabular}{|c|c|c|c|c|c|c|}
\hline Targeted drug & Target & In combination with & Phase & Setting & Locations & NCT number* \\
\hline Atezolizumab & PD-LI & $\begin{array}{l}\text { Platinum agent plus } \\
\text { gemcitabine }\end{array}$ & III & $\begin{array}{l}\text { Chemotherapy-naive } \\
\mathrm{SqCC} \text { of the lung and } \\
\text { nonsquamous }\end{array}$ & $\begin{array}{l}\text { Global, including } \\
\text { China }\end{array}$ & NCT02409342 \\
\hline Nimotuzumab & EGFR & Chemoradiotherapy & II & $\begin{array}{l}\text { Unresectable locally } \\
\text { advanced SqCC of } \\
\text { the lung (first-line or } \\
\text { previously treated) }\end{array}$ & China & NCT0257734I \\
\hline Nimotuzumab & EGFR & $\begin{array}{l}\text { Gemcitabine and } \\
\text { carboplatin }\end{array}$ & II & $\begin{array}{l}\text { Unresectable locally } \\
\text { advanced SqCC of } \\
\text { the lung (first-line) }\end{array}$ & China & NCT02428764 \\
\hline Icotinib & EGFR & None & II & $\begin{array}{l}\text { Resected-stage } \\
\text { IB EGFR mutant } \\
\text { NSCLC, including } \\
\text { SqCC of the lung } \\
\text { (first-line) }\end{array}$ & China & NCT02264210 \\
\hline $\begin{array}{l}\text { Four novel target } \\
\text { inhibitors (BYL7I9, } \\
\text { INC280, LDK378, and } \\
\text { MEK 162) }\end{array}$ & $\begin{array}{l}\text { PIK3CA; } \\
\text { c-MET; ALK } \\
\text { or ROSI; } \\
\text { KRAS, NRAS, } \\
\text { or BRAF }\end{array}$ & None & II & $\begin{array}{l}\text { Advanced NSCLC, } \\
\text { including SqCC of the } \\
\text { lung; line of therapy } \\
\text { unspecified }\end{array}$ & China & NCT02276027 \\
\hline Ipilimumab & CTLA-4 & Paclitaxel and carboplatin & III & $\begin{array}{l}\mathrm{SqCC} \text { of the lung; line } \\
\text { of therapy unspecified }\end{array}$ & $\begin{array}{l}\text { Global, includes } \\
\text { China }\end{array}$ & NCT0I 285609 \\
\hline Ipilimumab & CTLA-4 & Paclitaxel and carboplatin & III & $\begin{array}{l}\mathrm{SqCC} \text { of the lung; line } \\
\text { of therapy unspecified }\end{array}$ & $\begin{array}{l}\text { Some European } \\
\text { locations Korea, } \\
\text { Singapore, and } \\
\text { China }\end{array}$ & NCT02279732 \\
\hline Pembrolizumab & PD-I & $\begin{array}{l}\text { Carboplatin and paclitaxel } \\
\text { or nanoparticle albumin- } \\
\text { bound paclitaxel (nab- } \\
\text { paclitaxel) }\end{array}$ & III & $\begin{array}{l}\mathrm{SqCC} \text { of the lung } \\
\text { (first-line) }\end{array}$ & China & NCT02775435 \\
\hline
\end{tabular}

Note: *Accessed from ClinicalTrials.gov, September 2018.

Abbreviations: ALK, anaplastic lymphoma kinase; NCT, National Clinical Trial; NSCLC, non-small-cell lung cancer; PD-I, programmed death protein I; PD-LI, programmed death ligand-I; SqCC, squamous cell carcinoma.

in a first-in-human trial achieving a partial response; FGFR1 is overexpressed in $10 \%-20 \%$ of SqCC. ${ }^{15,80}$ In addition, phosphoinositide 3-kinase (PI3K) alpha inhibitors, such as BYL719, are also currently being clinically evaluated in SqCC of the lung (Table 3). The results of these trials are awaited with interest.

\section{Biomarker development for targeted therapies for $\mathrm{SqCC}$ of the lung}

A further assessment of the use of predictive biomarkers will help facilitate decisions on second-line therapy. Both ErbB family mutations, especially ErbB2, and VS-G status seem to be particularly useful in identifying a patient group who demonstrates long-term response to afatinib. Indeed, there are two ongoing trials of afatinib in Asian patients with advanced NSCLC, one focusing on patients with EGFR mutations (NCT01953913) and the other on patients with ErbB2 mutations (NCT02597946). In addition, the US National Cancer
Institute-Molecular Analysis for Therapy Choice study of afatinib includes groups of patients with EGFR or ErbB2 activating mutations (NCT02465060). The results of these trials are also eagerly awaited.

An ongoing study, Lung-MAP ${ }^{81}$ conducted in the USA, is assessing the personalization of second-line therapy for patients with $\mathrm{SqCC}$ of the lung according to their tumor mutations. Based on their genetic characteristics, each patient will be assigned to the trial substudy, which will evaluate an investigational agent that is best matched to their tumor's genomic profile vs standard of care chemotherapy as the comparator. The investigational agents include the following: nivolumab plus ipilimumab; erlotinib plus rilotumumab (hepatocyte growth factor inhibitor); palbociclib (cyclindependent kinase inhibitor); AZD4547 (FGFR1 inhibitor); durvalumab; and taselisib (PI3K inhibitor; NCT02154490).

There is some evidence that PD-L1 expression is a predictive biomarker for PD-1 inhibitors. ${ }^{71}$ Therefore, afatinib 
may be a suitable treatment option for patients who do not overexpress PD-L1 but have ErbB family mutations.

\section{Chinese perspectives and conclusions}

As lung cancer incidence and mortality continuously increase in China, ${ }^{1,2}$ a consensus on optimal treatment strategies is urgently needed to ensure that patients receive the best possible care, which is in line with best practice elsewhere in the world.

Guidelines for the management of primary lung cancer in China were last published in 2015, ${ }^{10}$ and since then, a number of targeted therapies have been approved for the treatment of SqCC of the lung, including necitumumab, pembrolizumab, nivolumab, ramucirumab, and afatinib. ${ }^{9}$ The so-called "drug-lag" may be a factor contributing to the delayed availability of other new anticancer agents. In China, there is a large backlog of pending applications for both clinical trial registrations and drug approvals, which is thought to be a consequence of the complexity of the approval process, the volume of applications, and a lack of resource available to process these applications. ${ }^{82}$ Whether the Chinese treatment guidelines should be updated immediately, or after other new anticancer agents that are available elsewhere have been approved for use in China, is a matter for debate.

As described above, the analyses of afatinib in a small number of Chinese patients suggest that improvements in long-term response $\mathrm{e}^{50}$ and patient-reported outcomes may be greater than that in Western populations. ${ }^{41,50,52}$ Among different ethnic populations, pharmacoethnic differences induced by differences in environmental and local medical practices have been noted, in addition to pharmacogenomic differences, which may affect treatment response. ${ }^{19}$ Therefore, factors related to patients' ethnicity may affect response to anticancer agents in different populations. These include the following: environmental factors influencing bioavailability and metabolism, such as smoking frequency, alcohol or herbal medicine use, and/or variations in local dietary patterns; local factors such as differences in medical care preferences; ethnicspecific drug-drug interactions and variability of genetic polymorphisms in drug metabolizing enzymes and transporters; and ethnic-specific mutations in a drug's receptor or target leading to a particular sensitivity or resistance to an individual drug. ${ }^{19}$

A number of specific challenges to effective cancer care in China have been identified, including disparities in health care access, environmental contamination, and inherent traditional attitudes toward cancer. ${ }^{83}$ While anticancer treatment cannot influence the latter two challenges, access to health care may be partly improved by the use of convenient anticancer therapies. As afatinib is available as oral tablets and in multiple strengths, it can be self-administered in an outpatient setting, with uncomplicated and effective tolerability-guided dose adjustments. ${ }^{14,84,85}$ These attributes may help simplify cancer treatment for patients with limited access to medical infrastructure, such as those living in remote areas, and help overcome one of the many challenges to effective cancer care in China. ${ }^{83}$

None of the clinical trials leading to the global approval of nivolumab, pembrolizumab, atezolizumab, and ramucirumab for second-line treatment of SqCC of the lung included the analysis of data from Chinese patients, meaning that there is a paucity of data to guide treatment decisions in this patient group. By contrast, data are available on outcomes of Chinese patients from the LUX-Lung 8 trial, which led to the global approval of afatinib, including approval in China, in this setting. The manageable efficacy, safety, ease of administration, and QoL data with afatinib indicate that it is a valid treatment option for Chinese patients with advanced SqCC of the lung who have progressed on or after platinum-based chemotherapy. In addition, the findings of the biomarker analyses conducted on LUX-Lung 8 data indicate that clinicians should consider testing all patients, including Chinese patients, for ErbB family mutations and VS-G profile, as these may be useful as predictive biomarkers for afatinib in SqCC of the lung.

Expanding second-line treatment options necessitates the selection of the optimal treatment choice and sequence, and the data reported from the ongoing trials with novel targeted therapies and potential biomarkers that include Chinese patients will aid such management decisions.

\section{Acknowledgments}

Medical writing assistance was provided by Sarah Maloney of GeoMed, an Ashfield company, part of UDG Healthcare plc, during the preparation of this article. The author was fully responsible for all content and editorial decisions, was involved in all stages of manuscript development, and approved the final version.

\section{Disclosure}

Medical writing assistance was supported financially by Boehringer Ingelheim. The author reports no other conflicts of interest in this work. 


\section{References}

1. Chen W, Zheng R, Zeng H, Zhang S. The incidence and mortality of major cancers in China, 2012. Chin J Cancer. 2016;35(1):73.

2. Hong QY, Wu GM, Qian GS, et al. Prevention and management of lung cancer in China. Cancer. 2015;121(S17):3080-3088.

3. Reitsma MB, Fullman N, Ng M, et al. Smoking prevalence and attributable disease burden in 195 countries and territories, 1990-2015: a systematic analysis from the global burden of Disease Study 2015. The Lancet. 2017;389(10082):1885-1906.

4. Li Q, Hsia J, Yang G. Prevalence of smoking in China in 2010. N Engl J Med. 2011;364(25):2469-2470.

5. Molina JR, Yang P, Cassivi SD, Schild SE, Adjei AA. Non-small cell lung cancer: epidemiology, risk factors, treatment, and survivorship. Mayo Clin Proc. 2008;83(5):584-594.

6. Giovino GA. Epidemiology of tobacco use in the United States. Oncogene. 2002;21(48):7326-7340.

7. Gao Y, Zhang JF, Li QC, et al. The clinicopathological and prognostic features of Chinese and Japanese inpatients with lung cancer. Oncotarget. 2016;7(41):67425-67434.

8. Meza R, Meernik C, Jeon J, Cote ML. Lung cancer incidence trends by gender, race and histology in the United States, 1973-2010. PLoS One. 2015;10(3):e0121323.

9. Novello S, Barlesi F, Califano R, et al. Metastatic non-small-cell lung cancer: ESMO clinical practice guidelines for diagnosis, treatment and follow-up. Ann Oncol. 2016;27(suppl 5):v1-v27.

10. Zhi X-Y, Yu J-M, Shi Y-K. Chinese guidelines on the diagnosis and treatment of primary lung cancer (2015 version). Cancer. 2015; 121(S17):3165-3181.

11. Reck M, Popat S, Reinmuth N, et al. Metastatic non-small-cell lung cancer (NSCLC): ESMO clinical practice guidelines for diagnosis, treatment and follow-up. Ann Oncol. 2014;25(suppl 3):iii27-iii39.

12. Hirsh V. New developments in the treatment of advanced squamous cell lung cancer: focus on afatinib. Onco Targets Ther. 2017;10:2513-2526.

13. Thatcher N, Hirsch FR, Luft AV, et al. Necitumumab plus gemcitabine and cisplatin versus gemcitabine and cisplatin alone as first-line therapy in patients with stage IV squamous non-small-cell lung cancer (SQUIRE): an open-label, randomised, controlled phase 3 trial. Lancet Oncol. 2015;16(7):763-774.

14. Boehringer Ingelheim International, GmbH. Gilotrif US prescribing information; 2016. Available from: https://docs.boehringer-ingelheim. com/Prescribing\%20Information/PIs/Gilotrif/Gilotrif.pdf. Accessed June 19, 2017.

15. Dienstmann R, Rodon J, Prat A, et al. Genomic aberrations in the FGFR pathway: opportunities for targeted therapies in solid tumors. Ann Oncol. 2014;25(3):552-563.

16. Li D, Ambrogio L, Shimamura T, et al. BIBW2992, an irreversible EGFR/HER2 inhibitor highly effective in preclinical lung cancer models. Oncogene. 2008;27(34):4702-4711.

17. Solca F, Dahl G, Zoephel A, et al. Target binding properties and cellular activity of afatinib (BIBW 2992), an irreversible ErbB family blocker. $J$ Pharmacol Exp Ther. 2012;343(2):342-350.

18. O'Donnell PH, Dolan ME. Cancer pharmacoethnicity: ethnic differences in susceptibility to the effects of chemotherapy. Clin Cancer Res. 2009;15(15):4806-4814.

19. Saijo N. The role of pharmacoethnicity in the development of cytotoxic and molecular targeted drugs in oncology. Yonsei Med J. 2013;54(1):1-14.

20. Sequist LV, Yang JC-H, Yamamoto N, et al. Phase III Study of Afatinib or Cisplatin Plus Pemetrexed in Patients With Metastatic Lung Adenocarcinoma With EGFR Mutations. JCO. 2013;31(27):3327-3334.

21. $\mathrm{Wu} \mathrm{YL,} \mathrm{Zhou} \mathrm{C,} \mathrm{Hu} \mathrm{CP,} \mathrm{et} \mathrm{al.} \mathrm{Afatinib} \mathrm{versus} \mathrm{cisplatin} \mathrm{plus} \mathrm{gemcitabine}$ for first-line treatment of Asian patients with advanced non-small-cell lung cancer harbouring EGFR mutations (LUX-Lung 6): an open-label, randomised phase 3 trial. Lancet Oncol. 2014;15(2):213-222.

22. Mok TS, Wu YL, Thongprasert S, et al. Gefitinib or carboplatinpaclitaxel in pulmonary adenocarcinoma. NEngl J Med. 2009;361(10): 947-957.
23. Mitsudomi T, Morita S, Yatabe Y, et al. Gefitinib versus cisplatin plus docetaxel in patients with non-small-cell lung cancer harbouring mutations of the epidermal growth factor receptor (WJTOG3405): an open label, randomised phase 3 trial. Lancet Oncol. 2010;11(2):121-128.

24. Maemondo M, Inoue A, Kobayashi K, et al. Gefitinib or chemotherapy for non-small-cell lung cancer with mutated EGFR. N Engl J Med. 2010; 362(25):2380-2388.

25. Zhou C, Wu YL, Chen G, et al. Erlotinib versus chemotherapy as first-line treatment for patients with advanced EGFR mutation-positive non-smallcell lung cancer (optimal, CTONG-0802): a multicentre, open-label, randomised, phase 3 study. Lancet Oncol. 2011;12(8):735-742.

26. Rosell R, Carcereny E, Gervais R, et al. Erlotinib versus standard chemotherapy as first-line treatment for European patients with advanced EGFR mutation-positive non-small-cell lung cancer (EURTAC): a multicentre, open-label, randomised phase 3 trial. Lancet Oncol. 2012;13(3):239-246.

27. Wu YL, Zhou C, Liam CK, et al. First-line erlotinib versus gemcitabine/ cisplatin in patients with advanced EGFR mutation-positive non-smallcell lung cancer: analyses from the phase III, randomized, open-label, ensure study. Ann Oncol. 2015;26(9):1883-1889.

28. Park K, Tan EH, O’Byrne K, et al. Afatinib versus gefitinib as first-line treatment of patients with EGFR mutation-positive non-small-cell lung cancer (LUX-Lung 7): a phase 2B, open-label, randomised controlled trial. Lancet Oncol. 2016;17(5):577-589.

29. Paz-Ares L, Tan E-H, O'Byrne K, et al. Afatinib versus gefitinib in patients with EGFR mutation-positive advanced non-small-cell lung cancer: overall survival data from the phase IIb LUX-Lung 7 trial. Ann Oncol. 2017;28(2):270-277.

30. Wu YL, Cheng Y, Zhou X, et al. Dacomitinib versus gefitinib as firstline treatment for patients with EGFR-mutation-positive non-small-cell lung cancer (ARCHER 1050): a randomised, open-label, phase 3 trial. Lancet Oncol. 2017;18(11):1454-1466.

31. Soria JC, Ohe Y, Vansteenkiste J, et al. Osimertinib in untreated EGFR-mutated advanced non-small-cell lung cancer. $N$ Engl J Med. 2018;378(2):113-125.

32. Paez JG, Jänne PA, Lee JC, et al. EGFR mutations in lung cancer: correlation with clinical response to gefitinib therapy. Science. 2004; 304(5676):1497-1500.

33. Sekine I, Yamamoto N, Nishio K, Saijo N. Emerging ethnic differences in lung cancer therapy. Br J Cancer. 2008;99(11):1757-1762.

34. Dearden S, Stevens J, Wu YL, Blowers D. Mutation incidence and coincidence in non small-cell lung cancer: meta-analyses by ethnicity and histology (mutMap). Ann Oncol. 2013;24(9):2371-2376.

35. Clinical Lung Cancer Genome Project, Network Genomic Medicine. A genomics-based classification of human lung tumors. Sci Transl Med. 2013;5209(209):ra153.

36. Gately K, Forde L, Cuffe S, et al. High coexpression of both EGFR and IGF1R correlates with poor patient prognosis in resected non-small-cell lung cancer. Clin Lung Cancer. 2014;15(1):58-66.

37. Hirsch FR, Varella-Garcia M, Bunn PA, et al. Epidermal growth factor receptor in Non-Small-Cell lung carcinomas: correlation between gene copy number and protein expression and impact on prognosis. JCO. 2003;21(20):3798-3807.

38. Lee HJ, Xu X, Choe G, et al. Protein overexpression and gene amplification of epidermal growth factor receptor in nonsmall cell lung carcinomas: comparison of four commercially available antibodies by immunohistochemistry and fluorescence in situ hybridization study. Lung Cancer. 2010;68(3):375-382.

39. Zugazagoitia J, Ponce S, Paz-Ares L. Necitumumab for first-line treatment of advanced, squamous, non-small-cell lung cancer: a relevant step forward? Transl Lung Cancer Res. 2016;5(1):95-97.

40. Pirker R. Epidermal growth factor receptor-directed monoclonal antibodies in nonsmall cell lung cancer. Curr Opin Oncol. 2015;27(2):87-93.

41. Soria JC, Felip E, Cobo M, et al. Afatinib versus erlotinib as secondline treatment of patients with advanced squamous cell carcinoma of the lung (LUX-Lung 8): an open-label randomised controlled phase 3 trial. Lancet Oncol. 2015;16(8):897-907. 
42. Pujol JL, Pirker R, Lynch TJ, et al. Meta-analysis of individual patient data from randomized trials of chemotherapy plus cetuximab as firstline treatment for advanced non-small cell lung cancer. Lung Cancer. 2014;83(2):211-218.

43. Clark GM, Zborowski DM, Santabárbara P, et al. Smoking history and epidermal growth factor receptor expression as predictors of survival benefit from erlotinib for patients with non-small-cell lung cancer in the National Cancer Institute of Canada Clinical Trials Group study BR.21. Clin Lung Cancer. 2006;7(6):389-394.

44. Leon L, Lee GS. Comparative efficacy and safety of erlotinib in nonsmall cell lung cancer (NSCLC) of squamous cell and adenocarcinoma histology in the phase III NCIC CTG BR.21 and SATURN (BO18192) trials. Annal Oncol. 2012;23(Suppl 9):ix419.

45. Garassino MC, Martelli O, Broggini M, et al. Erlotinib versus docetaxel as second-line treatment of patients with advanced non-small-cell lung cancer and wild-type EGFR tumours (tailor): a randomised controlled trial. Lancet Oncol. 2013;14(10):981-988.

46. Cancer Genome Atlas Research Network. Comprehensive genomic characterization of squamous cell lung cancers. Nature. 2012;489(7417): 519-525.

47. Ugocsai K, Mándoky L, Tiszlavicz L, Molnár J. Investigation of HER2 overexpression in non-small cell lung cancer. Anticancer Res. 2005; 25(4):3061-3066.

48. Yi ES, Harclerode D, Gondo M, et al. High c-erbB-3 protein expression is associated with shorter survival in advanced non-small cell lung carcinomas. Mod Pathol. 1997;10(2):142-148.

49. Heinmöller P, Gross C, Beyser K, et al. HER2 status in non-small cell lung cancer: results from patient screening for enrollment to a phase II study of Herceptin. Clin Cancer Res. 2003;9(14):5238-5243.

50. Lu S, Li W, Zhou C, et al. Afatinib versus erlotinib for second-line treatment of Chinese patients with advanced squamous cell carcinoma of the lung: a subgroup analysis of the phase 3 LUX-Lung 8 trial. Onco Targets Ther. 2018;11:8565-8573.

51. Yang JC-H, Goss G, Felip E, et al. 102PLUX-Lung 8 phase III trial: analysis of long-term response to second-line afatinib in patients with advanced squamous cell carcinoma (SCC) of the lung. Ann Oncol. 2017; 28(suppl_2):Poster 102.

52. Felip E, Hirsh V, Popat S, et al. Symptom and quality of life improvement in LUX-Lung 8, an open-label phase III study of second-line afatinib versus erlotinib in patients with advanced squamous cell carcinoma of the lung after first-line platinum-based chemotherapy. Clin Lung Cancer. 2018;19(1):74-83.

53. Yang JC, Reguart N, Barinoff J, et al. Diarrhea associated with afatinib: an oral ErbB family blocker. Expert Rev Anticancer Ther. 2013; 13(6):729-736.

54. Boehringer Ingelheim International, GmbH. Giotrif ${ }^{\circledR}$ afatinib becomes the first second-generation ErbB family blocker approved for lung cancer in China. Available from: https:/www.boehringer-ingelheim.com/ press-release/afatinib-approved-lung-cancer-china. Accessed June 19, 2017. Press Release.

55. Kim JH, Grossi F, de Marinis F. Afatinib monotherapy in patients with metastatic squamous cell carcinoma of the lung progressing after erlotinib/gefitinib (E/G) and chemotherapy: interim subset analysis from a phase III trial. J Clin Oncol. 2012;30(suppl 15): abstract 7558 .

56. Machiels JP, Haddad RI, Fayette J, et al. Afatinib versus methotrexate as second-line treatment in patients with recurrent or metastatic squamous-cell carcinoma of the head and neck progressing on or after platinum-based therapy (LUX-Head \& Neck 1): an open-label, randomised phase 3 trial. Lancet Oncol. 2015;16(5):583-594.

57. Le Tourneau C, Delord J-P, Dolivet G. Predictor (UNICANCER GEP11): randomized phase II study of preoperative afatinib in untreated head and neck squamous cell carcinoma (HNSCC) patients. J Clin Oncol. 2017;35 Suppl:Abstract 6021.

58. Lawrence MS, Stojanov P, Polak P, et al. Mutational heterogeneity in cancer and the search for new cancer-associated genes. Nature. 2013; 499(7457):214-218.
59. Gadgeel S, Goss G, Soria JC, et al. Evaluation of the VeriStrat ${ }^{\circledR}$ serum protein test in patients with advanced squamous cell carcinoma of the lung treated with second-line afatinib or erlotinib in the phase III LUXLung 8 study. Lung Cancer. 2017;109:101-108.

60. Dhanasekaran SM, Balbin OA, Chen G, et al. Transcriptome metaanalysis of lung cancer reveals recurrent aberrations in Nrg1 and Hippo pathway genes. Nat Commun. 2014;5(1):5893.

61. Goss GD, Felip E, Cobo M, et al. Association of ERBB mutations with clinical outcomes of afatinib- or erlotinib-treated patients with lung squamous cell carcinoma: secondary analysis of the LUX-Lung 8 randomized clinical trial. JAMA Oncol. 2018;4(9):1189-1197.

62. Jaiswal BS, Kljavin NM, Stawiski EW, et al. Oncogenic ErbB3 mutations in human cancers. Cancer Cell. 2013;23(5):603-617.

63. Frampton GM, Fichtenholtz A, Otto GA, et al. Development and validation of a clinical cancer genomic profiling test based on massively parallel DNA sequencing. Nat Biotechnol. 2013;31(11):1023-1031.

64. Taguchi F, Solomon B, Gregorc V, et al. Mass spectrometry to classify non-small-cell lung cancer patients for clinical outcome after treatment with epidermal growth factor receptor tyrosine kinase inhibitors: a multicohort cross-institutional study. J Natl Cancer Inst. 2007;99(11):838-846.

65. Carbone DP, Ding K, Roder H, et al. Prognostic and predictive role of the VeriStrat plasma test in patients with advanced non-small-cell lung cancer treated with erlotinib or placebo in the NCIC Clinical Trials Group BR.21 trial. J Thorac Oncol. 2012;7(11):1653-1660.

66. Gregorc V, Novello S, Lazzari C, et al. Predictive value of a proteomic signature in patients with non-small-cell lung cancer treated with second-line erlotinib or chemotherapy (PROSE): a biomarker-stratified, randomised phase 3 trial. Lancet Oncol. 2014;15(7):713-721.

67. Pardoll DM. The blockade of immune checkpoints in cancer immunotherapy. Nat Rev Cancer. 2012;12(4):252-264.

68. Stinchcombe TE. Unmet needs in squamous cell carcinoma of the lung: potential role for immunotherapy. Med Oncol. 2014;31(5):960.

69. Brahmer J, Reckamp KL, Baas P, et al. Nivolumab versus docetaxel in advanced squamous-cell non-small-cell lung cancer. $N$ Engl J Med. 2015;373(2):123-135

70. Hida T, Nishio M, Nogami N, et al. Efficacy and safety of nivolumab in Japanese patients with advanced or recurrent squamous non-small cell lung cancer. Cancer Sci. 2017;108(5):1000-1006.

71. Herbst RS, Baas P, Kim D-W, et al. Pembrolizumab versus docetaxel for previously treated, PD-L1-positive, advanced non-small-cell lung cancer (KEYNOTE-010): a randomised controlled trial. The Lancet. 2016; 387(10027):1540-1550.

72. Paz-Ares L, Luft AA, Vicente D. Pembrolizumab plus chemotherapy for squamous non-small-cell lung cancer. NEngl JMed. 2018;379(21): 2040-2051.

73. Fehrenbacher L, Spira A, Ballinger M, et al. Atezolizumab versus docetaxel for patients with previously treated non-small-cell lung cancer (POPLAR): a multicentre, open-label, phase 2 randomised controlled trial. The Lancet. 2016;387(10030):1837-1846.

74. Rittmeyer A, Barlesi F, Waterkamp D, et al. Atezolizumab versus docetaxel in patients with previously treated non-small-cell lung cancer $(\mathrm{OAK})$ : a phase 3, open-label, multicentre randomised controlled trial. The Lancet. 2017;389(10066):255-265.

75. Postow MA. Managing immune Checkpoint-Blocking antibody side effects. Am Soc Clin Oncol Educ Book. 2015;35:76-83.

76. Hanahan D, Weinberg RA. Hallmarks of cancer: the next generation. Cell. 2011;144(5):646-674.

77. Garon EB, Ciuleanu T-E, Arrieta O, et al. Ramucirumab plus docetaxel versus placebo plus docetaxel for second-line treatment of stage IV non-small-cell lung cancer after disease progression on platinum-based therapy (REVEL): a multicentre, double-blind, randomised phase 3 trial. The Lancet. 2014;384(9944):665-673.

78. Park K, Kim JH, Cho EK, et al. East Asian subgroup analysis of a randomized, double-blind, phase 3 study of docetaxel and ramucirumab versus docetaxel and placebo in the treatment of stage IV non-small cell lung cancer following disease progression after one prior platinumbased therapy (REVEL). Cancer Res Treat. 2016;48(4):1177-1186. 
79. Lynch TJ, Bondarenko I, Luft A, et al. Ipilimumab in combination with paclitaxel and carboplatin as first-line treatment in stage IIIB/IV Non-Small-Cell lung cancer: results from a randomized, double-blind, multicenter phase II study. JCO. 2012;30(17):2046-2054.

80. Wolf J, Lorusso PM, Camidge RD, et al. Abstract LB-122: a phase I dose escalation study of NVP-BGJ398, a selective pan FGFR inhibitor in genetically preselected advanced solid tumors. Cancer Research. 2012;72(8 Supplement):LB-122.

81. Ferrarotto R, Redman MW, Gandara DR, Herbst RS, Papadimitrakopoulou VA. Lung-MAP - framework, overview, and design principles. Chin Clin Oncol. 2015;4(3):36.

82. Zhou Q, Chen XY, Yang ZM, Wu YL. The changing landscape of clinical trial and approval processes in China. Nat Rev Clin Oncol. 2017;14(9): $577-583$.

83. Goss PE, Strasser-Weippl K, Lee-Bychkovsky BL, et al. Challenges to effective cancer control in China, India, and Russia. Lancet Oncol. 2014;15(5):489-538.
84. Boehringer Ingelheim. Giotrif summary of product characteristics; 2016. Available from: https://www.medicines.org.uk/emc/medicine/28353. Accessed February 7, 2018. Electronic Medicines Compendium (eMC).

85. Yang JC, Sequist LV, Zhou C, et al. Effect of dose adjustment on the safety and efficacy of afatinib for EGFR mutation-positive lung adenocarcinoma: post hoc analyses of the randomized LUX-Lung 3 and 6 trials. Ann Oncol. 2016;27(11):2103-2110.

86. Schuler M, Yang JC, Park K, et al. Afatinib beyond progression in patients with non-small-cell lung cancer following chemotherapy, erlotinib/gefitinib and afatinib: phase III randomized LUX-Lung 5 trial. Ann Oncol. 2016;27(3):417-423.

87. Institute for Health Metrics and Evaluation (IHME). GBD Compare. Seattle, WA: IHME, University of Washington, 2017. Available from: http://vizhub.healthdata.org/gbd-compare. Accessed January 15, 2019.
OncoTargets and Therapy

\section{Publish your work in this journal}

OncoTargets and Therapy is an international, peer-reviewed, open access journal focusing on the pathological basis of all cancers, potential targets for therapy and treatment protocols employed to improve the management of cancer patients. The journal also focuses on the impact of management programs and new therapeutic agents and protocols on

\section{Dovepress}

patient perspectives such as quality of life, adherence and satisfaction The manuscript management system is completely online and includes a very quick and fair peer-review system, which is all easy to use. Visit http://www.dovepress.com/testimonials.php to read real quotes from published authors. 